
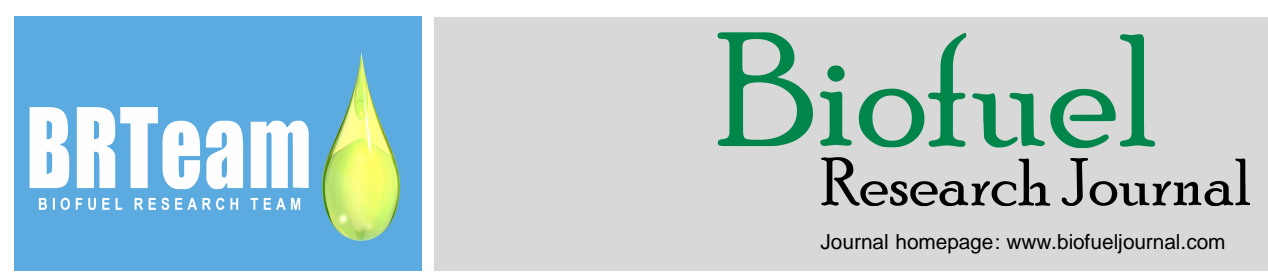

Original Research Paper

\title{
Qualitative role of heterogeneous catalysts in biodiesel production from Jatropha curcas oil
}

Fatai Alade Aderibigbe ${ }^{1, *}$, Sherif Ishola Mustapha ${ }^{1,2}$, Tunmise Latifat Adewoye ${ }^{1}$, Ishaq Alhassan Mohammed ${ }^{1}$, Adebola Bukola Gbadegesin ${ }^{1}$, Faith Emmanuel Niyi ${ }^{1}$, Opeyemi Idowu Olowu ${ }^{1}$, Akinpelumi Gabriel Soretire ${ }^{1}$, Harvis Bamidele Saka $^{1}$

${ }^{1}$ Department of Chemical Engineering, Faculty of Engineering and Technology, University of Ilorin, Ilorin, Nigeria.

${ }^{2}$ Department of Chemical Engineering, Durban University of Technology, South Africa.

\section{HIGHLIGHTS}

$>$ Tri-metallic (Fe-Co-Ni) catalyst was synthesized through two different techniques; green synthesis and wet impregnation.

$>$ Impacts of synthsis method and support material on final bioduesel product was scrutinized. $>$ Catalyst support material/synthesis method influenced the yield of the produced biodiesel. $>$ Catalyst support/synthesis method influenced the composition and propeties of the resultant biodiesel. $>$ Green-synthesized Fe-Co-Ni-MgO catalyst led to highest biodiesel yield of $97.9 \%$

\section{GRAPHICAL ABSTRACT}

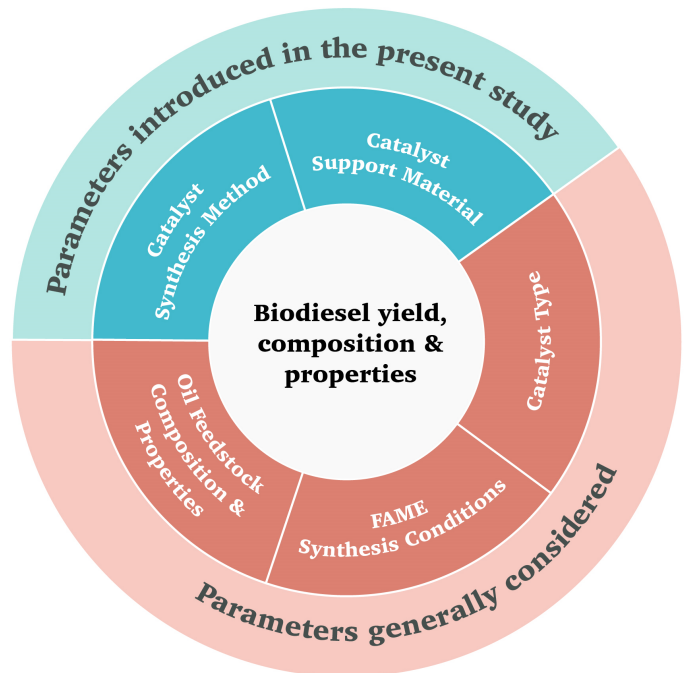

\section{ARTICLE INFO}

\section{Article history:}

Received 19 December 2019

Received in revised form 26 March 2020

Accepted 27 March 2020

Available online 1 June 2020

\section{Keywords:}

Green synthesis

Wet impregnation

Jatropha curcas oil

Biodiesel

Unsaturation

FAME profile

\begin{abstract}
Biodiesel properties are in general attributed to the composition and properties of the oil feedstock used, overlooking the possible impacts of the catalyst preparation details. In light of that, the impacts of different catalyst preparation techniques alongside those of different support materials on the yield, composition, and fuel properties of biodiesels produced from the same oil feedstock were investigated. More specifically, tri-metallic (Fe-Co-Ni) catalyst was synthesized through two different techniques (green synthesis and wet impregnation) using $\mathrm{MgO}$ or $\mathrm{ZnO}$ as support material. The generated catalyst pairs, i.e., $\mathrm{Fe}$ - $\mathrm{Co}-\mathrm{Ni} / \mathrm{MgO}$ and $\mathrm{Fe}$ - $\mathrm{Co}$ $\mathrm{Ni} / \mathrm{ZnO}$ prepared by wet impregnation and $\mathrm{Fe}-\mathrm{Co}-\mathrm{Ni}-\mathrm{MgO}$ and $\mathrm{Fe}-\mathrm{Co}-\mathrm{Ni}-\mathrm{ZnO}$ prepared by green synthesis (using leaf extracts) were used in the transesterification process of Jatropha curcas oil. Detailed morphological properties, composition, thermal stability, crystalline nature, and functional groups characterization of the catalysts were also carried out. Using Box-Behnken Design response surface methodology, it was found that the green-synthesized $\mathrm{Fe}-\mathrm{Co}-\mathrm{Ni}-\mathrm{MgO}$ catalyst resulted in the highest biodiesel yield of $97.9 \%$. More importantly, the fatty acid methyl ester (FAME) profiles of the biodiesels produced using the four catalysts as well as their respective fuel properties were different in spite of using the same oil feedstock.
\end{abstract}

(c) 2020 BRTeam. All rights reserved.

* Corresponding authors at: Tel.: +234 8033822123

E-mail address: aderibigbe.fa@ unilorin.edu.ng

Please cite this article as: Aderibigbe F.A., Mustapha S.I., Adewoye T.L., Mohammed I.A., Gbadegesin A.B., Niyi F.E., Olowu O.I., Soretire A.G., Saka H.B. Qualitative role of heterogeneous catalysts in biodiesel production from Jatropha curcas oil. Biofuel Research Journal 26 (2020) 1159-1169. DOI: 10.18331/BRJ2020.7.2.4 


\section{Introduction}

There have been several literature reports on the influences that biodiesel chemical structure such as its degree of unsaturation could have on engine performance, combustion, and emissions characteristics (Lapuerta et al., 2009; Benjumea et al., 2010; Sokoto et al., 2011; Altun, 2014; Yang et al., 2016; Hellier et al., 2017; Folayan et al., 2019). For instance, the work of Benjumea et al. (2010) has shown that a higher degree of unsaturation of biodiesel fuels causes a more retarded start of combustion, while Gopinath et al. (2010) showed that biodiesels having more unsaturated fatty acids emit more oxides of nitrogen and exhibit lower thermal efficiency compared to biodiesels having more saturated acids.

Overall, biodiesel properties depend on the properties of the various individual fatty esters constituting the fuel which are in turn determined by the structural features of their fatty acid and alcohol moieties (Refaat, 2009). Exactly for this reason, factors such as molecular structure and composition of the oil feedstocks and alcohols are principally considered to optimize the performance of the final biodiesel fuel (Refaat, 2009). Extensive studies on various oils have considered the use of different catalysts to obtain biodiesels of specific fatty acid methyl ester (FAME) profiles and qualities (Omotoso et al., 2011; Sharmila et al., 2016; Gupta and Agarwal, 2016; Cruz-Ortiz and Ríos-González, 2017). Commonly, these studies conclude that the oils used are responsible for the chemical structures and properties of the produced biodiesel. However, there seem to be some ambiguities as the possible involvement of catalyst type and synthesis route in determining FAME profiles is not generally monitored nor reported on in these studies. Consequently, from most of the previous investigations, it is difficult to infer the exact role of catalysts and their selectivity towards the formation of particular methyl ester molecules.

It should also be noted that the quantitative role of catalysts (i.e., impact on yield) has been the focus of many past studies and been properly addressed (Kaisan et al., 2016; Sharma et al., 2018). While the qualitative impacts of catalysts in influencing the type of methyl esters (saturated/unsaturated) were largely ignored possibly due to the fact that oil feedstock and its fatty acid profile is regarded as the most important parameter.

Currently, the state-of-art in rational design of catalysts involves the development of predictive models using different computational methods and their validation with experiments (synthesis, characterization, and performance tests). Machine learning algorithms are particularly useful as they can find complex correlations from large data sets. Catalysts exhibit complex structureproperty-activity relationship, thus an efficient means of discovering improved catalysts is with the rational design of catalysts since physical insights are combined with data to construct predictive models, which lead to design principles for identifying promising candidate catalysts. Systematic experiments are then performed for validating the activity of a predicted catalyst, providing further physical insights while assisting with refining the predictive models and design principles (Tsai, 2017). Existing computational heterogeneous catalysis tools include predictive modeling, density functional theory (DFT), scaling correlations (adsorption scaling relations and transition state energies), micro-kinetic modeling, and volcano relations (descriptorbased models). A good review of the general optimization framework for rational design of catalysts can be found in Wang and Hu (2016) and Tsai (2017).

Yet, the future of heterogeneous catalysis is faced with our limited understanding of catalysts' behavior under dynamic reaction conditions (Kalz et al., 2017). The structure of catalysts is very dynamic and in-depth studies of catalysts and catalytic reactors under such transient conditions have only started recently. For instance, the generation of corresponding pool of candidate structures is already a daunting task for steady-state operation and will not become easier for dynamic operation (Kalz et al., 2017). Kalz et al. (2017) suggests an intensive exchange between the fields of 1) operando spectroscopy including time-resolved methods, 2) theory with predictive quality, 3) kinetic modelling, 4) design of catalysts by appropriate preparation concepts, and 5) novel/modular reactor designs, to address the challenges faced.

In biodiesel production, heterogeneous catalysts are preferred because they are more economical given their easy separation from the reaction mixture and reusability (Al-Muhtaseb et al., 2018). Moreover, biodiesel production can be eco-friendlier and more economic if such catalysts are utilized (Al-Muhtaseb et al., 2018).
Bimetallic heterogeneous catalysts have been well studied for a wide range of applications in energy production and environmental remediation due to their tunable properties which are governed by compositions of the metallic systems, preparation method, and morphostructure (De et al. 2016). Such bimetallic catalysts as $\mathrm{Ca} / \mathrm{Fe}$ (Kwong and Yung, 2015), AuAg (Banerjee et al., 2014), Ni-W supported on Al-MCM-41 (Yang et al. 2019), W-Zr/CaO (Nasar and Taufiq-Yap, 2017), Mo-Mn, Mo-Zn, and Mo-Sn supported on $\gamma-\mathrm{Al}_{2} \mathrm{O}_{3}-\mathrm{MgO}$ (Farooq et al., 2016) have been studied and were found efficient for the production of biodiesel. Nevertheless, trimetallic catalysts have been reported to offer superior catalytic properties compared to the mono- and bimetallic types (Yin et al., 2017). For instance, the superior catalytic performance of $\mathrm{Fe}-\mathrm{Co}-\mathrm{Ni}$ catalyst over $\mathrm{Fe}-\mathrm{Co}, \mathrm{Fe}-\mathrm{Ni}$, $\mathrm{Co}-\mathrm{Ni}$ or their monometallic forms was experimentally shown by Abdulkareem et al. (2017). Recently, ternary and quaternary metal complexes such as $\mathrm{Cu} / \mathrm{Ni} / \mathrm{Ca} / \mathrm{Al}_{2} \mathrm{O}_{3}$ and $\mathrm{Cu} / \mathrm{Zn} / \mathrm{Ca} / \mathrm{Al}_{2} \mathrm{O}_{3}$ were shown to be capable of producing methyl esters with high yield and quality (Kamal, 2018).

Our lack of sufficient understanding in this emerging field necessitates further studies to obtain more in-depth insights. Therefore, trimetallic transition metal catalysts, delineated across support materials, were prepared by wet impregnation and green synthesis methods and were used to produce biodiesel from physic nut (Jatropha curcas) oil. More specifically, the impacts of different catalysts on the degree of unsaturation and FAME profiles of biodiesels produced from an identical oil feedstock were investigated. The findings could pave the way for more rational design of heterogeneous catalysts using any of the several available optimization frameworks to obtain catalysts with features of interest.

\section{Materials and Methods}

\subsection{Materials}

Analytical grade chemicals (Sigma-Aldrich) were used in this study. The $J$. curcas oil used was obtained from the University of Ilorin $J$. curcas plantation. Other materials used are Amaranthus spinopus leaves, Citrus aurantifolia leaves, phenolphthalein (indicator), distilled water, de-ionized water and paper foil.

\subsection{Methodology}

\subsubsection{Determination of acid value and free fatty acid of Jatropha Curcas} oil

To determine the acid value, $25 \mathrm{~mL}$ of ethanol was added to diethyl ether $(25 \mathrm{~mL})$ and the mixture was then mixed with $0.1 \mathrm{M} \mathrm{NaOH}$. A few drops of phenolphthalein solution serving as the indicator was also added. About 10 $\mathrm{g}$ of $J$. curcas oil was dissolved in the mixture followed by titration against $0.1 \mathrm{M} \mathrm{NaOH}$ until a pink color was obtained. The acid values and the percentage of free fatty acid (FFA\%) were measured according to standard methods (Gardy et al., 2010), using Equations 1 and 2:

$$
\begin{aligned}
& \text { Acid value }\left(\frac{m g K O H}{g}\right)=\frac{\left(V_{b s}-V_{b}\right) \times C \times 56.11}{W} \\
& \text { Free fatty acid }(\%)=\frac{\left(V_{b s}-V_{b}\right) \times C \times 28.246}{W}
\end{aligned}
$$

where $V_{\mathrm{bs}}$ is the consumed volume of titrate for biodiesel sample $(\mathrm{mL})$; $V_{\mathrm{b}}$ denotes the consumed volume of titrate for the blank $(\mathrm{mL}) ; C$ stands for the exact concentration of standardized alcoholic potassium hydroxide solution (mole/L), and $W$ is the mass of biodiesel sample used $(\mathrm{g})$.

\subsubsection{Preparation of catalysts}

Tri-metallic catalyst of iron, cobalt, and nickel supported on magnesium oxide was prepared by the wet impregnation technique $(\mathrm{Fe}-\mathrm{Co}-\mathrm{Ni} / \mathrm{MgO})$ and a green synthesis route using a plant extract $(\mathrm{Fe}-\mathrm{Co}-\mathrm{Ni}-\mathrm{MgO})$. Moreover, tri-metallic catalyst of iron, cobalt, and nickel supported on zinc oxide was prepared by the wet impregnation technique $(\mathrm{Fe}-\mathrm{Co}-\mathrm{Ni} / \mathrm{ZnO})$ and the green synthesis route $(\mathrm{Fe}-\mathrm{Co}-\mathrm{Ni}-\mathrm{ZnO})$. 


\section{(a) Wet impregnation synthesis of $\mathrm{Fe}-\mathrm{Co}-\mathrm{Ni} / \mathrm{MgO}$ and $\mathrm{Fe}-\mathrm{Co}-\mathrm{Ni} / \mathrm{ZnO}$ catalysts}

The $\mathrm{Fe}-\mathrm{Co}-\mathrm{Ni} / \mathrm{MgO}$ or $\mathrm{Fe}-\mathrm{Co}-\mathrm{Ni} / \mathrm{ZnO}$ catalyst was prepared by dissolving equimolar quantities of the nitrate salts of $\mathrm{Fe}, \mathrm{Co}$, and $\mathrm{Ni}(1: 1: 1)$ in deionized water followed by mixing with $16 \mathrm{~g}$ of $\mathrm{MgO}$ or $\mathrm{ZnO}$. The mixture was allowed to stand for $60 \mathrm{~min}$, and followed by drying at $120^{\circ} \mathrm{C}$ for $8 \mathrm{~h}$. It was subsequently screened with a $150 \mu \mathrm{m}$ sieve, and was calcined at $500^{\circ} \mathrm{C}$ for $3 \mathrm{~h}$.

\section{(b) Green synthesis of $\mathrm{Fe}-\mathrm{Co}-\mathrm{Ni}-\mathrm{MgO}$ catalyst}

First, unripe leaves of A. spinosus were collected and washed thoroughly with distilled water. The fresh leaves were chopped into small pieces and were subsequently reduced to a paste using a mortar and pestle. The fine paste was used in the preparation of the leaf extract. Distilled water $(100 \mathrm{~mL})$ was added to $20 \mathrm{~g}$ of the paste which was transferred carefully into a $250 \mathrm{~mL}$ Erlenmeyer flask and was magnetically stirred at $100^{\circ} \mathrm{C}$ for $30 \mathrm{~min}$. The extract obtained was filtered and the clear extract was stored for use in the synthesis of colloidal $\mathrm{MgO}$ particles. The extract was characterized using Fourier-transform infrared spectroscopy (FTIR) spectroscopy to check for the various functional groups present.

An equimolar solution of iron, cobalt, and nickel nitrates (1:1:1) was prepared, stirred at $50^{\circ} \mathrm{C}$ for 30 min using a magnetic stirrer, dried at $120^{\circ} \mathrm{C}$ for about $2 \mathrm{~h}$, and was finally calcined at $500^{\circ} \mathrm{C}$ for $3 \mathrm{~h}$. The sample was stored for future use to provide the $\mathrm{Fe}, \mathrm{Co}$, and $\mathrm{Ni}$ active metals of the catalyst.

A $1 \mathrm{M}$ solution of $\mathrm{Mg}\left(\mathrm{NO}_{3}\right)_{2} \cdot 6 \mathrm{H}_{2} \mathrm{O}$ was prepared as the source for magnesium oxide nanoparticles, stirred at $50^{\circ} \mathrm{C}$ for about $10 \mathrm{~min}$ using a magnetic stirrer to allow for the proper mixing of the solution. Then, $50 \mathrm{~mL}$ of the prepared leaf extract solution was added to the solution while continuously stirred magnetically. The color of the mixture was found to be greenish at first but after being stirred continuously for about $20 \mathrm{~min}$, a marked reduction in the intensity of the color was noticed. The UV-Vis spectrum of the mixture was then recorded to confirm the formation of the $\mathrm{MgO}$ nanoparticles (Fig. S1).

Finally, the $\mathrm{Fe}-\mathrm{Ni}-\mathrm{Co}-\mathrm{MgO}$ catalyst was prepared by adding $3 \mathrm{~g}$ of the calcined sample to the mixture containing the $\mathrm{MgO}$ nanoparticles and stirred magnetically at $50^{\circ} \mathrm{C}$ for about $20 \mathrm{~min}$ to increase the homogeneity of the sample. This mixture was then dried at $120^{\circ} \mathrm{C}$ for $2 \mathrm{~h}$ and was subsequently calcined at $500^{\circ} \mathrm{C}$ for $3 \mathrm{~h}$. The calcined material was recovered and stored for use in the biodiesel production process.

\section{(c) Green synthesis of $\mathrm{Fe}-\mathrm{Co}-\mathrm{Ni}$-ZnO catalyst}

The $\mathrm{Fe}-\mathrm{Co}-\mathrm{Ni}-\mathrm{ZnO}$ catalyst was prepared by hybridization in which the $\mathrm{Fe}$, $\mathrm{Ni}$, and Co were obtained by direct dissolution and mixing of their nitrate salts in deionized water, while $\mathrm{ZnO}$ was derived from the reduction of its nitrate salt by the whole extract of $C$. aurantifolia leaves. The unripe leaves of $C$. aurantifolia were collected, washed thoroughly with distilled water, and reduced in size using a mortar and pestle. Then, $20 \mathrm{~g}$ of the mashed $C$. aurantifolia leaves was added to $100 \mathrm{~mL}$ of distilled water in a $250 \mathrm{~mL}$ Erlenmeyer flask and stirred at $100^{\circ} \mathrm{C}$ for 30 min using a magnetic stirrer. The obtained extract was mixed and filtered. The filtrate was kept in the refrigerator until use. The leaf extract was characterized by the FTIR spectroscopy to identify the functional groups present in the sample.

Zinc nitrate hexahydrate, $\mathrm{Zn}\left(\mathrm{NO}_{3}\right)_{2} \cdot 6 \mathrm{H}_{2} \mathrm{O}$, served as the precursor for synthesis of $\mathrm{ZnO}$ nanoparticles. The precursor solution was prepared by dissolving $20 \mathrm{~g}$ of $\mathrm{Zn}\left(\mathrm{NO}_{3}\right)_{2} \cdot 6 \mathrm{H}_{2} \mathrm{O}$ in $50 \mathrm{~mL}$ of distilled water. This solution was then stirred at $50^{\circ} \mathrm{C}$ for 30 min using a magnetic stirrer. Thereafter, about $50 \mathrm{~mL}$ of leaf extract was added to the solution and this mixture was boiled until it was reduced to a deep yellow colored paste.

The sources of iron, cobalt, and nickel metals in the catalyst were their corresponding nitrate salts, i.e., $\mathrm{Fe}\left(\mathrm{NO}_{3}\right)_{3} \cdot 9 \mathrm{H}_{2} \mathrm{O}, \mathrm{Co}\left(\mathrm{NO}_{3}\right)_{2} \cdot 6 \mathrm{H}_{2} \mathrm{O}$, and $\mathrm{Ni}$ $\left.\left(\mathrm{NO}_{3}\right)_{2} \cdot 6 \mathrm{H}_{2} \mathrm{O}\right)$. A $0.01 \mathrm{M}$ precursor solution containing $\mathrm{Fe}, \mathrm{Co}$, and $\mathrm{Ni}(1: 1: 1)$ was prepared, and stirred at $50^{\circ} \mathrm{C}$ for $30 \mathrm{~min}$ using a magnetic stirrer. The mixture was dried for $3 \mathrm{~h}$ and calcined at $400^{\circ} \mathrm{C}$ for $3 \mathrm{~h}$ resulting in a fine black powder.

The $\mathrm{Fe}-\mathrm{Ni}-\mathrm{Co}-\mathrm{ZnO}$ catalyst was finally prepared by mixing the calcined material (fine black powder) with the deep yellow colored paste obtained from zinc nitrate, and was stirred at $50^{\circ} \mathrm{C}$ for $30 \mathrm{~min}$. The mixture was then calcined at $500^{\circ} \mathrm{C}$ for $2 \mathrm{~h}$.

\subsubsection{Characterization of catalysts}

The four synthesized catalysts: (a) $\mathrm{Fe}-\mathrm{Co}-\mathrm{Ni} / \mathrm{MgO}$, (b) $\mathrm{Fe}-\mathrm{Co}-\mathrm{Ni}-\mathrm{MgO}$, (c) $\mathrm{Fe}-\mathrm{Co}-\mathrm{Ni} / \mathrm{ZnO}$, and (d) $\mathrm{Fe}-\mathrm{Co}-\mathrm{Ni}-\mathrm{ZnO}$ were characterized for their crystalline nature, morphological properties, elemental compositions, functional groups, and thermal stability using X-ray powder diffraction (XRD), scanning electron microscope with an energy dispersive X-ray spectrometer (SEM-EDS), FTIR, and thermal gravimetric analysis (TGA), respectively. The XRD analysis was performed on a Bruker AXS D8 Advance (USA) with $\mathrm{Cu}-\mathrm{K} \alpha$ radiation. A portion of the crystals were sprinkled on a de-greased glass slide, and diffractograms were recorded between diffraction angles of $15^{\circ}$ and $80^{\circ}$. The SEM morphology results of the synthesized catalysts were acquired using a high-resolution Zeiss Auriga (USA). A crystal sample $(1 \mathrm{mg})$ was sprinkled onto a carbon adhesive tape and sputter coated with Au-Pd using a Quorum T15OT for 5 min prior to the analysis. The microscope was operated with an electron high tension at $5 \mathrm{kV}$ for imaging. In the FTIR analysis, infrared light in the range $500-4000 \mathrm{~cm}^{-1}$ was used to scan the sample. The sample was prepared using a standard potassium bromide $(\mathrm{KBr})$ and was then placed on a crystal in the Nicholet iS5 spectrometer. In the TGA procedure, small quantity of the sample was placed on the sample pan and the TGA-DSC analysis was performed using a TGA SDT Q600 instrument (TA Instruments). The programmed heating range was from room temperature $\left(30^{\circ} \mathrm{C}\right)$ to $800^{\circ} \mathrm{C}$ at the rate of $10^{\circ} \mathrm{C} \cdot \mathrm{min}^{-1}$ under nitrogen atmosphere.

\subsubsection{Optimization of biodiesel production}

The catalysts $(\mathrm{Fe}-\mathrm{Co}-\mathrm{Ni} / \mathrm{MgO}, \mathrm{Fe}-\mathrm{Co}-\mathrm{Ni} / \mathrm{ZnO}, \mathrm{Fe}-\mathrm{Co}-\mathrm{Ni}-\mathrm{MgO}$, and $\mathrm{Fe}$ $\mathrm{Co}-\mathrm{Ni}-\mathrm{ZnO}$ ) as prepared were employed in producing biodiesel using $J$. curcas oil and methanol. From several experimental runs conducted (Table 1), optimal conditions for biodiesel yield were identified for each of the catalysts used. Optimization of biodiesel production was performed using Box-Behnken Design (BBD), a response surface methodology by varying the reaction temperature, reaction time, methanol to oil molar ratio, and catalyst concentration.

Table 1.

Design of experiment for biodiesel production

\begin{tabular}{lcccc}
\hline Factors & $\begin{array}{c}\text { Temperature } \\
\left({ }^{\circ} \mathbf{C}\right)\end{array}$ & $\begin{array}{c}\text { MeOH:Oil molar } \\
\text { ratio }(\mathbf{w} / \mathbf{w})\end{array}$ & $\begin{array}{c}\text { Catalyst } \\
\text { concentration } \\
(\% \text { w/w of oil) }\end{array}$ & $\begin{array}{c}\text { Reaction } \\
\text { time }(\mathbf{h})\end{array}$ \\
\hline Level 1 & 50 & $10: 1$ & 5 & 1 \\
Level 2 & 55 & $15: 1$ & 10 & 2 \\
Level 3 & 60 & $20: 1$ & 15 & 3 \\
\hline
\end{tabular}

Experiments were carried out in $20 \mathrm{~mL}$ test tubes placed in a water bath shaker with a constant temperature. In a typical run, $1 \mathrm{~g}$ of $J$. curcas oil was measured into the test tube. Then, $2 \mathrm{~mL}$ of hexane was added to the oil to serve as a co-solvent and enhance the miscibility of oil with methanol and to speed up the rate of transesterification. Known amounts of catalyst (5\%, $10 \%$, or $15 \%$ w/w of oil) and methanol (methanol to oil ratio; $10: 1,15: 1$, or 20:1) were added to the mixture and stirred vigorously using a constant agitation speed, while maintained at a certain temperature $\left(50,55\right.$, or $\left.60^{\circ} \mathrm{C}\right)$ and for a certain reaction duration $(1,2$, or $3 \mathrm{~h})$. Upin the completion of reaction time, $5 \mathrm{~mL}$ of $\mathrm{n}$-hexane and $5 \mathrm{~mL}$ of distilled water were added to the products (biodiesel and glycerol), giving rise to two distinct phases which were separated from each other using a separating funnel. The catalyst and glycerol were dispersed in the water phase (the lower phase) while the biodiesel was dispersed in the $n$-hexane phase (the upper phase) Biodiesel was recovered from the mixture with $n$-hexane by heating until $\mathrm{n}$-hexane was evaporated. The catalyst was then regenerated by filtering the products in the water phase, followed by drying. The yield of biodiesel was calculated using Equation 3;

Yield $(\%)=\frac{\text { Weight of biodiesel }}{\text { Weight of oil }} \times 100$ 


\subsubsection{Properties of biodiesel}

The quality of the produced biodiesel was investigated by determining its physicochemical properties such as flash point, density, and viscosity. It was also characterized by using Gas Chromatography-Mass Spectroscopy (GCMS) to investigate functional groups present, as well as the geometry and spatial isomerism of the produced biodiesel. An Agilent 7890A gas chromatograph (USA) hyphenated to a 5975C mass spectrophotometer with triple axis detector equipped with an auto-injector $(10 \mu \mathrm{L}$ syringe $)$ was used. Helium was used as carrier gas. All chromatographic separation was performed on a capillary column having the following specifications: length; $30 \mathrm{~m}$, internal diameter $0.2 \mu \mathrm{m}$, thickness; $250 \mu \mathrm{m}$, and treated with phenyl methyl silox. Other GC-MS conditions included ion-source temperature: $250{ }^{\circ} \mathrm{C}$, interface temperature: $300{ }^{\circ} \mathrm{C}$, pressure: $0.1117 \mathrm{MPa}$, out time: $1.8 \mathrm{~mm}, 1 \mu \mathrm{l}$ injector in split mode with the split ratio of 1:50 and with an injection temperature of $300{ }^{\circ} \mathrm{C}$. The column temperature was set at $35^{\circ} \mathrm{C}$ for $5 \mathrm{~min}$ and was elevated to $150{ }^{\circ} \mathrm{C}$ at the rate of $4{ }^{\circ} \mathrm{C} / \mathrm{min}$, the temperature was the raised again to $250{ }^{\circ} \mathrm{C}$ at the rate of $20^{\circ} \mathrm{C} / \mathrm{min}$ and held for $5 \mathrm{~min}$. The total elution was $47.5 \mathrm{~min}$. MS solution software provided by the manufacturer was used to control the system and to acquire data. Identification of the compounds was carried out by comparing the mass spectra obtained with those of the standard mass spectra from the NIST library (NIST11)

\section{Results and Discussion}

\subsection{Leave extracts and formation of colloidal nanoparticles}

\subsubsection{Amaranthus spinosus extract and colloidal $\mathrm{MgO}$}

The FTIR spectrum of A. spinosus leaf extract is presented in Figure S2, showing characteristic bands for several functional groups. The spectrum analysis confirmed the presence of amaranthine and phenolic compounds, functional groups in the leave extract. The absorption band at $3445.91 \mathrm{~cm}^{-1}$ implies the presence of strong $\mathrm{OH}$ as well as $\mathrm{NH}$ stretching of phenol and amine group. The presence of carbonyl functional group around $1631.66 \mathrm{~cm}^{-1}, \mathrm{C}-\mathrm{O}$ group around $1159.89 \mathrm{~cm}^{-1}$, and $>\mathrm{C}=\mathrm{O}$ at about $1064.91 \mathrm{~cm}^{-1}$ are also observed. The result obtained agrees in part with those of the previous works by Das et al. (2012) and Muthukumar and Matheswaran (2015) who also observed hydroxyl, aromatic amines, aliphatic amines, carbonyl, $\mathrm{C}-\mathrm{H}$, and $\mathrm{C}=\mathrm{C}$ (benzene) functional groups.

Being effective reducing and capping agents, the presence of these groups in the leaf extract assisted with the formation of nanoparticles from the precursor solution. Presented in the Figure S1 is the UV-Vis spectrum of the colloidal $\mathrm{MgO}$ nanoparticles that were formed by using the green synthesis route.

The solution containing the $\mathrm{MgO}$ nanoparticles was analyzed using a UVVis spectrophotometer to confirm the formation of the particles. The resulting absorbance peak at $330 \mathrm{~nm}$ confirmed the successful formation of the $\mathrm{MgO}$ nanoparticles.

\subsubsection{Extract of Citrus aurantifolia and colloidal $\mathrm{ZnO}$}

Figure $\mathrm{S} 3$ shows the FTIR spectrum of $C$. aurantifolia leaf extract. The band at $570.98 \mathrm{~cm}^{-1}$ is associated to the $\mathrm{CH}_{2}$ group deformation. The $\mathrm{C}-\mathrm{O}$ of aliphatic acid groups are attributed to the peak from $1216.89 \mathrm{~cm}^{-1}$. The medium strong band at $1641.16 \mathrm{~cm}^{-1}$ is assigned to the deformation $\mathrm{C}-\mathrm{OH}$ of carboxyl. The intense absorption peak around $3493.40 \mathrm{~cm}^{-1}$ indicates the existence of free and intermolecular bonded hydroxyl groups. The $\mathrm{OH}$ stretching vibrations occur within a broad range of frequencies indicating the presence of "free" hydroxyl groups and bonded $\mathrm{OH}$ groups of carboxylic acids (Andronie et al., 2017). The presence of these compounds suggests that the leaf extract is a suitable reducing agent that could effectively precipitate out the zinc oxide from the zinc nitrate precursor.

\subsection{Characterization of catalysts}

\subsubsection{Crystalline nature of the catalysts}

The XRD patterns of the catalysts prepared by the green synthesis and wet impregnation methods were acquired and are presented in Figures 1a-d. All catalyst samples were shown to be crystalline, forming complex metal oxides of the metals involved. The identified peaks of $\mathrm{MgO}$ and $\mathrm{ZnO}$ shown in Figures $1 \mathrm{~b}$ and $1 \mathrm{~d}$ reveal that the nitrate salts of magnesium and zinc which were used as starting materials during the green synthesis method were adequately reduced to their respective oxides by the leave extracts of A. spinosus and C. aurantifolia, respectively. In Figure $1 \mathrm{a}$, the $\mathrm{MgO}$ is seen to exhibit four peaks at $2 \theta$ angles of $37.0^{\circ}, 42.8^{\circ}, 62.3^{\circ}$, and $78.5^{\circ}$ mainly due to $\mathrm{MgO}$ - periclase (JCPDS card No.00-045-0946).

In the XRD pattern of green synthesized $\mathrm{Fe}-\mathrm{Co}-\mathrm{Ni}-\mathrm{MgO}$ shown in Figure $1 \mathrm{~b}$, the peaks at $35.5^{\circ}, 44.0^{\circ}, 43.0^{\circ}, 62.3^{\circ}$, and $78.6^{\circ}$ represent majorly $\mathrm{MgFe}_{2} \mathrm{O}_{4}$ phase - magnesioferrite (JCPDS card No.00-036-0398). Some other peaks representing $\mathrm{MgO}$ - periclase (JCPDS card No. 00-045-0946) were also observed.

The XRD analysis of the wet impregnation-prepared $\mathrm{Fe}-\mathrm{Co}-\mathrm{Ni} / \mathrm{ZnO}$ catalyst is presented in Figure 1c. The major peaks at $31.7^{\circ}, 34.5^{\circ}, 36.2^{\circ}$, $47.5^{\circ}, 56.6^{\circ}, 62.9^{\circ}, 66.3^{\circ}, 67.9^{\circ}, 69.1^{\circ}, 72.5^{\circ}$, and $76.9^{\circ}$ indicate the presence

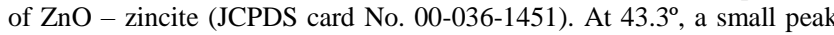
confirms the presence of NiO (JCPDS card No.00-047-1049). The sharpest peak occurring at $36.2^{\circ}$ denotes the $\mathrm{ZnO}$ present in the nanocatalyst which is highly crystalline. In Figure 1d, the XRD pattern of the green synthesized $\mathrm{Fe}-\mathrm{Co}-\mathrm{Ni}-\mathrm{ZnO}$ is presented. In addition to the highly crystalline nature, very similar result was obtained compared to the XRD pattern of $\mathrm{Fe}-\mathrm{Co}-\mathrm{Ni} / \mathrm{ZnO}$ catalyst prepared by the wet impregnation method (Fig. 1c).

Moreover, major peaks at $2 \theta$ angles of $31.8,34.4,36.3,47.5,56.6,62.9$, 67.9 , and $72.5^{\circ}$ were identified, showing the presence of $\mathrm{ZnO}$ - zincite (JCPDS card No. 00-036-1451). The peak at $34.4^{\circ}$ indicates the presence of $\mathrm{NiO}$. The peaks corresponding to individual metallic particles ( $\mathrm{Fe}, \mathrm{Co}$ or $\mathrm{Ni}$ ) were not detected possibly due to their low concentrations in the mixture.

\subsubsection{Morphological characteristics of the catalysts}

Despite similar starting materials used as precursors in their preparation, the four catalysts exhibited distinct morphologies due to their different methods of synthesis.

\section{(a) The SEM analysis of $\mathrm{Fe}-\mathrm{Co}-\mathrm{Ni} / \mathrm{MgO}$ catalyst}

High resolution SEM images of the $\mathrm{Fe}-\mathrm{Co}-\mathrm{Ni} / \mathrm{MgO}$ catalyst are shown in Figures 2a-d. The SEM was used to investigate the morphological characteristics of the catalyst and the extent of deposition of the active metals on the support. As shown in Figure 2a, the SEM result at $100 \mathrm{~nm}$ scale depicts clustered solid catalyst material that is crystalline, in which particles are near-spherical in geometry. Agglomerates seen in the SEM image could have formed from the drying process during sample preparation. The material is observed to exhibit micro-porous structure (Figs. 2c and d); lower magnification images at $1 \mu \mathrm{m}$ and $10 \mu \mathrm{m}$ ). Homogeneous appearance of the material's surface is indicative that $\mathrm{Fe}, \mathrm{Co}$ and $\mathrm{Ni}$ nanoparticles were properly dispersed on the $\mathrm{MgO}$ support material.

\section{(b) The SEM analysis of Fe-Co-Ni-MgO catalyst}

Figures 3a-d present the SEM results of the green-synthesized $\mathrm{Fe}$ - $\mathrm{Co}$ $\mathrm{Ni}-\mathrm{MgO}$ catalyst, showing a regular structure which is well defined with smaller nanosized particles dispersed over its surface (Figs. 3a and b). The regular structure is presumably that of $\mathrm{MgO}$ caused by combined chemical effect and thermal treatment. While Figures $3 \mathrm{a}$ and $3 \mathrm{~b}$ show clearly the deposition of smaller crystals of $\mathrm{Fe}, \mathrm{Co}$, and $\mathrm{Ni}$ onto the larger $\mathrm{MgO}$ particles. These images (Figs. 3a and b) also suggest that the larger tetrahedron particles be in the order of microns. An approximate estimation of the size of the nanoparticles dispersed on the surfaces is in the sub-100 nm range. In Figure 3d which depicts the catalyst material in clusters, the catalyst is shown to be porous and should therefore have abundant active reaction sites.

\section{(c) The SEM analysis of $\mathrm{Fe}-\mathrm{Co}-\mathrm{Ni} / \mathrm{ZnO}$ catalyst}

Presented in Figures 4a-d are the SEM images of the $\mathrm{Fe}-\mathrm{Co}-\mathrm{Ni} / \mathrm{ZnO}$ catalyst synthesized by wet impregnation. The small nanoparticles of $\mathrm{Fe}$, 

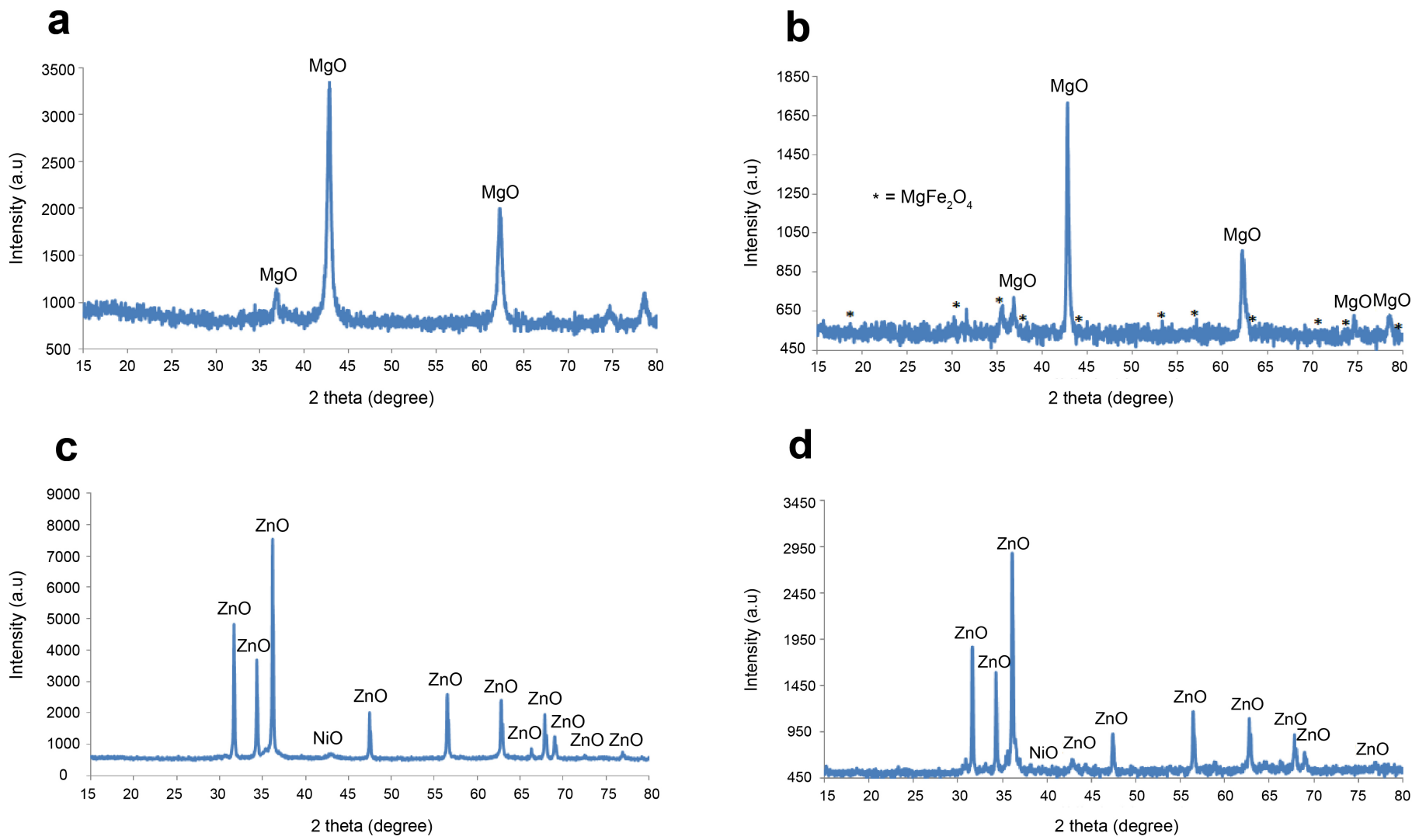

Fig. 1. XRD pattern of (a) $\mathrm{Fe}$ - $\mathrm{Co}-\mathrm{Ni} / \mathrm{MgO}$ catalyst prepared by wet impregnation, (b) $\mathrm{Fe}$ - $\mathrm{Co}-\mathrm{Ni}-\mathrm{MgO}$ catalyst prepared by green synthesis, (c) $\mathrm{Fe}$ - $\mathrm{Co}-\mathrm{Ni} / \mathrm{ZnO}$ catalyst prepared by wet impregnation, and (d) $\mathrm{Fe}$-Co-Ni-ZnO catalyst prepared by green synthesis.
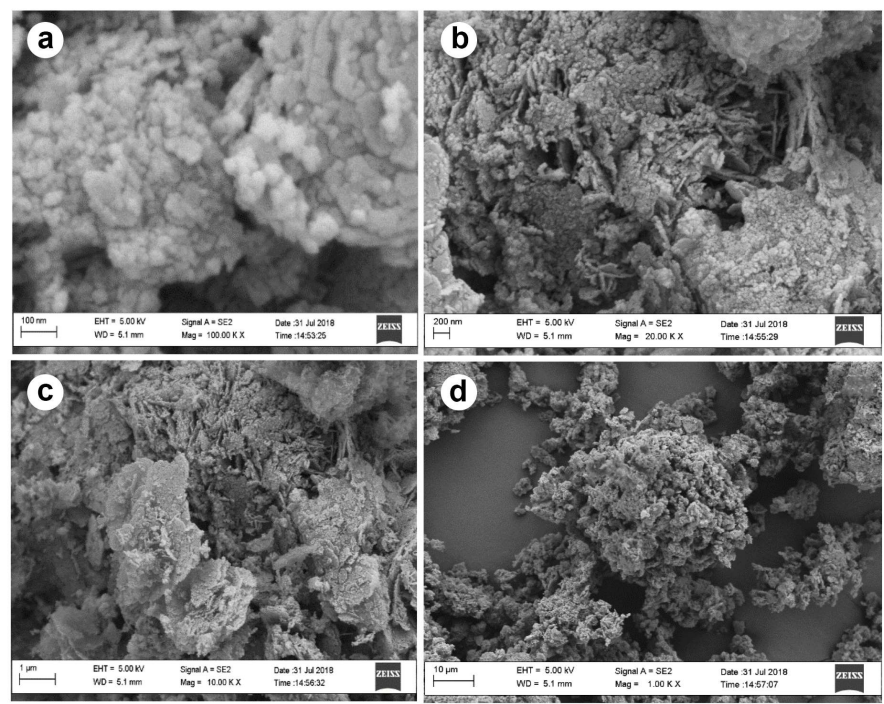

Fig. 2. High resolution SEM image of the $\mathrm{Fe}-\mathrm{Co}-\mathrm{Ni} / \mathrm{MgO}$ catalyst obtained at different scales of (a) $100 \mathrm{~nm}$, (b) $200 \mathrm{~nm}$, (c) $1 \mu \mathrm{m}$, and (d) $10 \mu \mathrm{m}$

$\mathrm{Co}$, and $\mathrm{Ni}$, and the $\mathrm{ZnO}$ support material can be observed. The SEM images shown in Figures $4 \mathrm{a}$ and $4 \mathrm{~b}$ represent three dimensional particles of nearspherical shape that are highly crystalline. The high crystallinity is in agreement with the XRD result presented earlier in Figure 1. The deposition of iron, cobalt, and nickel nanoparticles on the zinc oxide support is clearly seen as represented by particles in the sub- $20 \mathrm{~nm}$ size range. In Figures $4 \mathrm{c}$ and $4 d$,
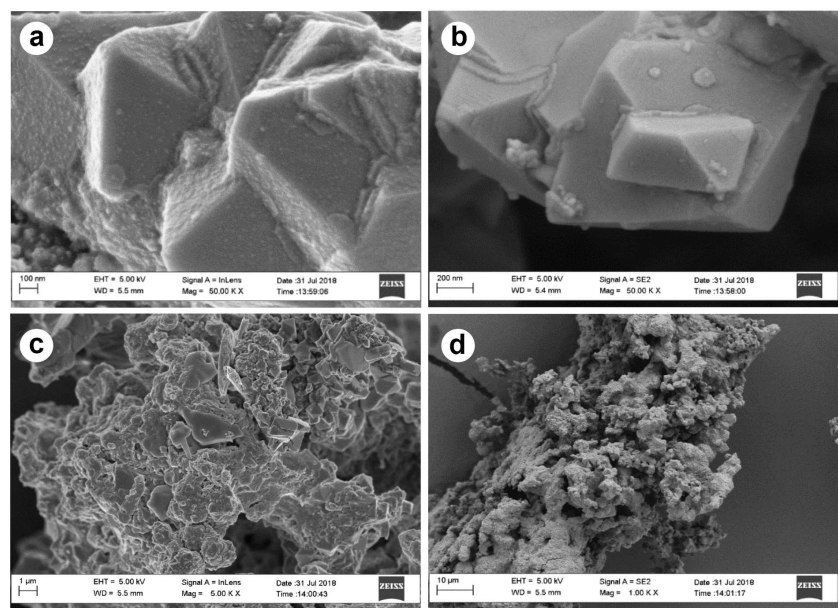

Fig. 3. High resolution SEM image of the $\mathrm{Fe}-\mathrm{Co}-\mathrm{Ni}-\mathrm{MgO}$ catalyst obtained at different scale of (a) $100 \mathrm{~nm}$, (b) $200 \mathrm{~nm}$, (c) $1 \mu \mathrm{m}$, and (d) $10 \mu \mathrm{m}$.

small micro-pores could be identified. It was also revealed that there was an even dispersion/distribution of the metals onto the $\mathrm{ZnO}$ support material.

\section{(d) The SEM analysis of Fe-Co-Ni-ZnO catalyst}

In the catalysts prepared by the wet impregnation method, phase distinction between the deposited active components and the support 

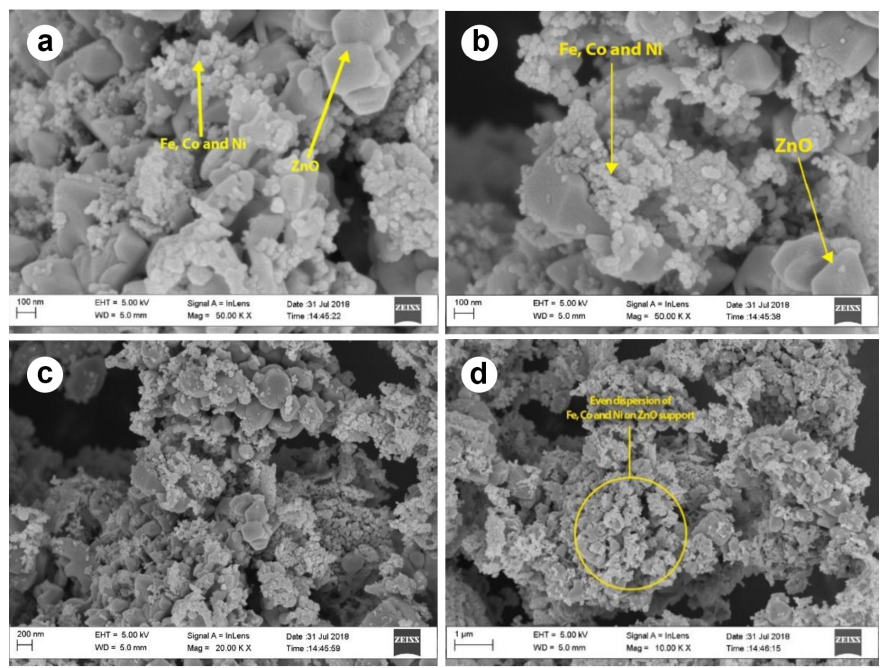

Fig. 4. High resolution SEM images of the $\mathrm{Fe}-\mathrm{Co}-\mathrm{Ni} / \mathrm{ZnO}$ catalyst at different scales of (a,b) 100 $\mathrm{nm}$, (c) $200 \mathrm{~nm}$, and (d) $1 \mu \mathrm{m}$.

material could be observed (Figs. 2 and 4). In contrast, the catalysts prepared by the green synthesis method appeared bespoke (Figs. 3 and 5). The $\mathrm{Fe}$ - $\mathrm{Co}$ $\mathrm{Ni}-\mathrm{ZnO}$ catalyst synthesized by the green synthesis route, as shown in Figures 5a-d, exhibited regular near-spherical structures with a narrow particle size distribution (Figs. 5a and 5b), which are characteristics of bespoke green nanomaterials. All the nanoparticles were within the sub-10 $\mathrm{nm}$ particle size range, with some agglomerated to form bigger particle clusters (Fig. 5b). Similar to the morphology difference observed between the $\mathrm{Fe}$ - $\mathrm{Co}-\mathrm{Ni} / \mathrm{MgO}$ and $\mathrm{Fe}$ - $\mathrm{Co}-\mathrm{Ni}-\mathrm{MgO}$ catalysts prepared by the wet impregnation and green synthesis methods, the $\mathrm{Fe}$ - $\mathrm{Co}-\mathrm{Ni}-\mathrm{ZnO}$ catalyst obtained through the green synthesis route also showed a morphology that was different from its wet impregnation counterpart. Moreover, the solid catalyst material was highly crystalline (Figs. $5 \mathrm{c}$ and $\mathrm{d}$ ), which was also evident from the related XRD results (Fig. 1d). Micropores could also be identified in the catalyst composite.
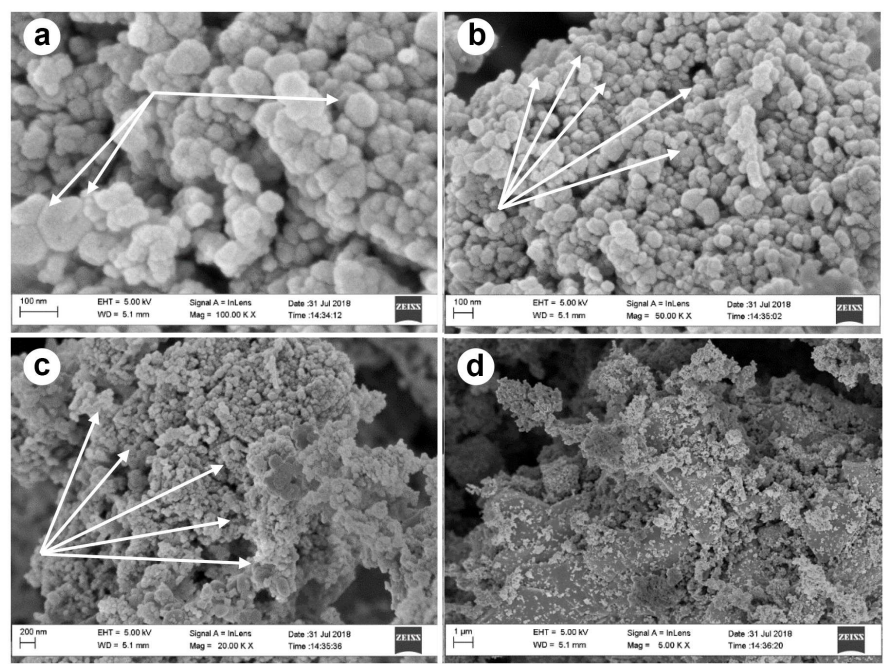

Fig. 5. High resolution SEM images showing $\mathrm{Fe}-\mathrm{Co}-\mathrm{Ni}-\mathrm{ZnO}$ catalyst at different scales of (a) 100 $\mathrm{nm}$, (b) $100 \mathrm{~nm}$, (c) $200 \mathrm{~nm}$, and (d) $1 \mu \mathrm{m}$.

\subsubsection{Elemental composition}

In the EDS qualitative and quantitative elemental analyses of all the four catalysts, metallic $\mathrm{Fe}, \mathrm{Co}, \mathrm{Ni}, \mathrm{Mg}$, and $\mathrm{Zn}$ were found. Based on the EDS results, the presence of the $\mathrm{Fe}, \mathrm{Co}, \mathrm{Ni}, \mathrm{Mg}$, and $\mathrm{Zn}$ metals around the line energy position of oxygen indicate the formation of complex oxides of these metals with oxygen. The EDS elemental analysis also showed that carbon is present in all the samples because carbon was used as the coating material during the EDS analysis. Carbon is the recommended coating materials as it does not interfere with the characteristics X-ray peaks from elements in samples. The EDS results are presented in Figure S4.

In the qualitative EDS result of the $\mathrm{Fe}-\mathrm{Co}-\mathrm{Ni} / \mathrm{MgO}$ catalyst presented in Figure S4a, the elemental composition in the catalyst was found as (in atomic \%): $\mathrm{C}$ (12.71), $\mathrm{O}(46.64), \mathrm{Mg}(35.45), \mathrm{Fe}(1.55), \mathrm{Co}(1.05)$, and $\mathrm{N}$ (2.61).

The EDS of the green synthesized $\mathrm{Fe}-\mathrm{Co}-\mathrm{Ni}-\mathrm{MgO}$ catalyst (Fig. S4b) presented atomic \% elemental composition of $\mathrm{C}(12.74), \mathrm{O}(36.54)$ $\mathrm{Mg}(33.11), \quad \mathrm{Cl}(4.56), \quad \mathrm{K}(0.24), \quad \mathrm{Fe}(3.15), \quad \mathrm{Co}(3.49), \quad$ and $\mathrm{Ni}(6.17)$ Obviously, $\mathrm{Mg}, \mathrm{O}, \mathrm{Fe}, \mathrm{Co}$, and $\mathrm{Ni}$ were introduced by the precursor salts, while $\mathrm{Cl}$ and $\mathrm{K}$ were from the leaf extract. In this case, carbon could be from the plant extract or coating material used during sample preparation for the EDS analysis.

The $\mathrm{Fe}-\mathrm{Co}-\mathrm{Ni} / \mathrm{ZnO}$ catalyst prepared by wet impregnation presented EDS elemental composition of $\mathrm{C}(29.22), \mathrm{O}(28.17), \mathrm{Na}(6.33), \mathrm{Fe}(3.62)$, $\mathrm{Co}(1.4), \mathrm{Ni}(2.85)$, and $\mathrm{Zn}(28.4)$ (in atomic \%). Again, carbon was introduced from the coating material during the EDS sample preparation stage, and $\mathrm{Na}$ was an impurity. The presence of oxygen is indicative of formation of complex oxides of the $\mathrm{Fe}, \mathrm{Co}, \mathrm{Ni}$, and $\mathrm{Zn}$ metals. These components are were found in the qualitative EDS result shown in Figure S4c.

In Figure S4d, the qualitative EDS result of the green-synthesized $\mathrm{Fe}$ $\mathrm{Co}-\mathrm{Ni}-\mathrm{ZnO}$ catalyst is presented. Its atomic \% elemental composition was found as $\mathrm{C}(19.65), \mathrm{O}(36.13), \mathrm{K}(0.46), \mathrm{Fe}(6.74), \mathrm{Co}(7.98), \mathrm{Ni}(12.4)$, and $\mathrm{Zn}(16.64)$. The composition of $\mathrm{Fe}-\mathrm{Co}-\mathrm{Ni}-\mathrm{ZnO}$ significantly differed from that of $\mathrm{Fe}-\mathrm{Co}-\mathrm{Ni} / \mathrm{ZnO}$, thus implying potentially different catalytic activity. Based on the EDS results, oxides of $\mathrm{Fe}, \mathrm{Co}, \mathrm{Ni}$, and $\mathrm{Zn}$ might have been formed. Carbon could be from the leaf extract or EDS coating material as mentioned earlier. The metals $\mathrm{Fe}, \mathrm{Co}$, and $\mathrm{Ni}$ are from the salt precursor while $\mathrm{K}$ might have been introduced by the leaf extract.

\subsubsection{Thermal stability}

The thermal behavior of the prepared catalysts was investigated using the TGA/DSC analyses over a temperature range of up to $900^{\circ} \mathrm{C}$ at the rate of $10^{\circ} \mathrm{C} \mathrm{min}-1$ under nitrogen atmosphere. Accordingly, the catalysts prepared by the wet impregnation technique were found to be more thermally stable than their equivalent ones prepared by the green synthesis method.

Figure 6a reveals that the $\mathrm{Fe}-\mathrm{Co}-\mathrm{Ni} / \mathrm{MgO}$ catalyst was thermally stable, losing only about $6 \mathrm{wt} \%$ of its original weight by rising the temperature up to $900^{\circ} \mathrm{C}$. A two-step thermal degradation and weight loss was first observed; at $100-200^{\circ} \mathrm{C}$, and $220-320^{\circ} \mathrm{C}$. The first weight loss could represent the loss of absorbed moisture while the second might be ascribed to the elimination of the crystal water. But a weight gain regime was also observed which occurred at above $550^{\circ} \mathrm{C}$. The initiation of a third weight loss regime above $300^{\circ} \mathrm{C}$ could be attributed to the decomposition of magnesium oxide while the subsequent weight gain could be indicative of phase transformation, involving the formation of new compound(s) $\mathrm{Mg}(\mathrm{OH})_{2}$.

In the TGA/DSC curves of $\mathrm{Fe}$ - $\mathrm{Co}-\mathrm{Ni}-\mathrm{MgO}$ (Fig. 6b), there are several regimes of weight loss which is typical of a mixture of many components exhibiting their individual thermal degradation. As one would expect, the leaf extract contained several phytochemicals and must have presumably introduced these to the catalyst material, possibly by forming complexes with the $\mathrm{Fe}, \mathrm{Co}, \mathrm{Ni}$, and $\mathrm{Mg}$ metal cations or their oxides. Throughout the heating up to $800^{\circ} \mathrm{C}$, this catalyst lost about $12 \mathrm{wt} \%$ of its initial weight. Of these, about $7 \mathrm{wt} \%$ was lost below $220^{\circ} \mathrm{C}$ which could be attributed to several volatile compounds from the green source. Apart from the weight loss prior to $220^{\circ} \mathrm{C}$, a weight loss was observed at $300-550^{\circ} \mathrm{C}$, and another at $720-820^{\circ} \mathrm{C}$. Some decomposition also occurred in this material thereby changing its thermal degradation behavior; the latter two regimes could be attributed to the degradation of individual components which could be complex compounds that had formed. Agglomeration and grain growth forming large crystalline structures with sizes in microns was also observed in the high resolution SEM images of this sample (Fig. 3). 
Overall, given their total weight loss percentages at above $800^{\circ} \mathrm{C}, \mathrm{Fe}$ - $\mathrm{Co}$ $\mathrm{Ni} / \mathrm{MgO}$ could be regarded as more thermally stable compared with $\mathrm{Fe}$ - $\mathrm{Co}-\mathrm{Ni}$ $\mathrm{MgO}$.
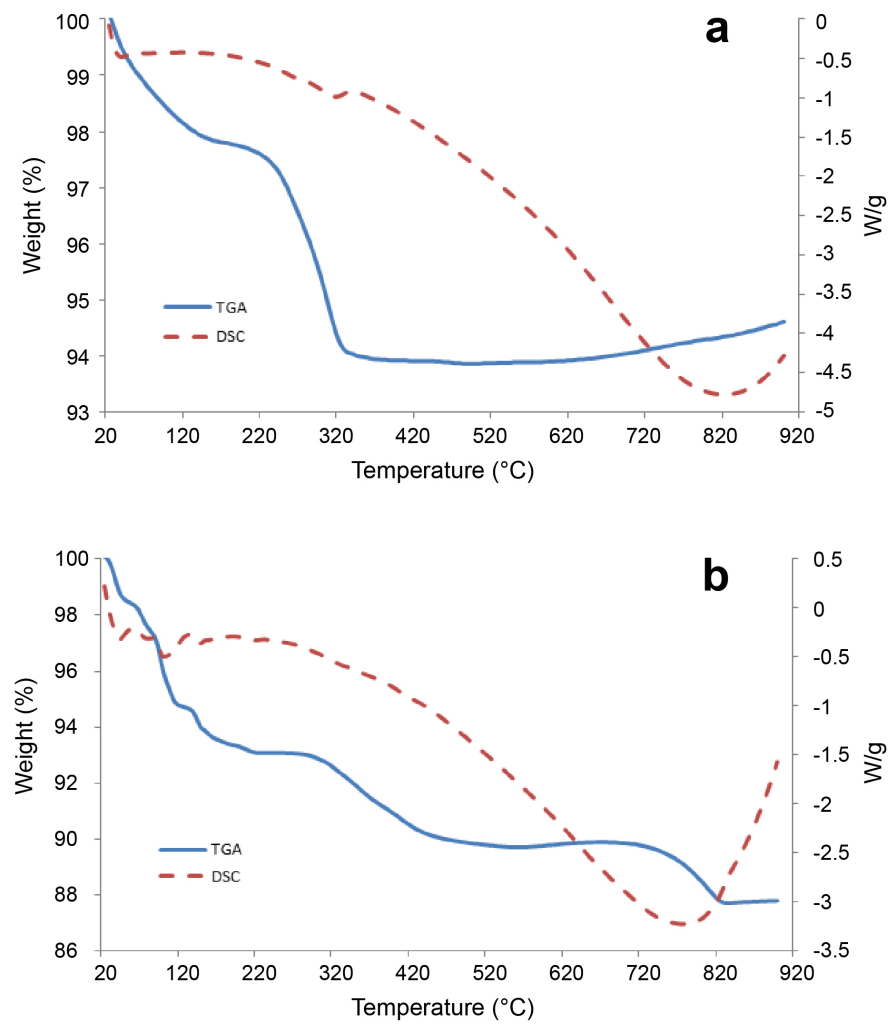

Fig. 6. TGA/DSC of (a) $\mathrm{Fe}-\mathrm{Co}-\mathrm{Ni} / \mathrm{MgO}$ catalyst (wet impregnation method), and (b) $\mathrm{Fe}-\mathrm{Co}-\mathrm{Ni}$ $\mathrm{MgO}$ catalyst (green synthesis method)

\subsubsection{Functional groups}

Remarkable observation can be made from the FTIR spectra of the catalysts, comparing $\mathrm{Fe}$ - $\mathrm{Co}-\mathrm{Ni} / \mathrm{MgO}$ with $\mathrm{Fe}$ - $\mathrm{Co}-\mathrm{Ni}-\mathrm{MgO}$, and $\mathrm{Fe}$ - $\mathrm{Co}-\mathrm{Ni} / \mathrm{ZnO}$ with $\mathrm{Fe}$ $\mathrm{Co}-\mathrm{Ni}$-ZnO. The pairs show similar FTIR spectra which further prove that their compositions, i.e., their surface functional groups, are at large alike. For instance, the spectra of $\mathrm{Fe}-\mathrm{Co}-\mathrm{Ni} / \mathrm{MgO}$ and $\mathrm{Fe}-\mathrm{Co}-\mathrm{Ni}-\mathrm{MgO}$ as presented in Figures $\mathrm{S} 5$ and $\mathrm{S} 6$ respectively, share broad and narrow bands, stretches, and vibrations at similar wavelengths.

In the FTIR spectrum of $\mathrm{Fe}-\mathrm{Co}-\mathrm{Ni} / \mathrm{MgO}$ presented in Figure S5, the medium peaks at $3699.21 \mathrm{~cm}^{-1}$ and $3458.58 \mathrm{~cm}^{-1}$ are the result of stretching O-H bonded to the surface of solids derived from adjacent water molecules (Andronie et al., 2017; Sutapa et al., 2018). The medium peak at $1670.35 \mathrm{~cm}^{-1}$ could derive from the asymmetric vibrations (vas) of $\mathrm{C}-\mathrm{O}$ in $\mathrm{Mg}$-oxalate complex, and the peak at $1381.53 \mathrm{~cm}^{-1}$ could be assigned to the symmetry vibration (vs) $\mathrm{C}-\mathrm{O}$ and $\delta(\mathrm{O}-$ C-O) (Sutapa et al., 2018).

The FTIR spectrum of $\mathrm{Fe}-\mathrm{Co}-\mathrm{Ni}-\mathrm{MgO}$ catalyst presented in Figure S6 shows major absorption bands occurring at 3654.88, 3632.72, 3449.08, $3325.59,1625.33,1435.36$, and $577.31 \mathrm{~cm}^{-1}$ which could be attributed to the asymmetric stretches, out of plane bends and in-plane bend vibration modes. These denote free and bonded alcohols and phenols $(\mathrm{O}-\mathrm{H}$ stretch $)$, nitramines $\left(\mathrm{NO}_{2}\right.$ stretch), alkanes/alkyl groups, alkenes $(\mathrm{C}=\mathrm{C}-\mathrm{H}$ in plane bends $)$, and alkynes ( $\mathrm{C}-\mathrm{H}$ bend), indicating that the functional groups such as flavones must have been transformed whilst acting as reducing and capping agents in the nanoparticle formation. Various other minor absorption bands occurred at $2898.15,2828.50,1530.34,1476.52,1349.87,1302.37$, and $830.61 \mathrm{~cm}^{-1}$ which could be assigned to alkanes (methyl, methylene, and methane) (C-H stretch), aromatic ( 2 or 3 bends only) $(\mathrm{C}=\mathrm{C}$ stretch), alkenes/alkyl groups, aromatics and meta-distributed benzene ( $\mathrm{C}-\mathrm{H}$ deformed vibrations).

Similarly, the spectra of $\mathrm{Fe}-\mathrm{Co}-\mathrm{Ni} / \mathrm{ZnO}$ and $\mathrm{Fe}-\mathrm{Co}-\mathrm{Ni}-\mathrm{ZnO}$ presented in Figures S7 and S8 were observed to share bands, stretches, and vibrations at the same wavelengths. In Figure S7, the absorption band at $3474.41 \mathrm{~cm}$ 1 indicates the presence of $-\mathrm{OH}$ hydroxyl groups. The $1615.83 \mathrm{~cm}^{-1}$ absorption band reveals the presence of $-\mathrm{C}=\mathrm{O}$ functional group stretching deformation and that at $992.08 \mathrm{~cm}^{-1}$ suggests the presence of $-\mathrm{C}-\mathrm{O}$ stretching deformation. The presence of $\mathrm{C}-\mathrm{H}$ functional group deforming vibration is represented by the peaks at $1492.35 \mathrm{~cm}^{-1}$ and $881.27 \mathrm{~cm}^{-1}$, while the presence of $\mathrm{C}-\mathrm{N}$ stretching vibration is indicated by the band recorded at $1356.20 \mathrm{~cm}^{-1}$.

The FTIR spectrum of the green-synthesized $\mathrm{Fe}-\mathrm{Co}-\mathrm{Ni}$ - $\mathrm{ZnO}$ shown in Figure S8 reveals the presence of aromatics and alkanes/alkyl groups. The absorption bands at $1587.34 \mathrm{~cm}^{-1}$ and $1558.84 \mathrm{~cm}^{-1}$ indicate the presence of $\mathrm{C}=\mathrm{C}$ functional groups. The absorption bands at $1482.85 \mathrm{~cm}^{-1}, 1448.02 \mathrm{~cm}$ ${ }^{1}$, and $1381.53 \mathrm{~cm}^{-1}$ represent the presence of $\mathrm{C}-\mathrm{H}$ deforming vibration. Generally, despite the observed similarities in their functional groups, the participation of each pair of the four catalysts in the transesterification reaction may not present similar activities because of the influences of the other structural factors of the catalytic materials.

\subsection{Optimization of biodiesel production}

The performance of the four synthesized catalysts in the transesterification reaction was investigated by varying reaction parameters in a Box-Behnken Design (BBD) of experiment as tabulated in Table 1. Each experiment had 27 experimental runs and the optimum value was identified in each case. The summary of the BBD experimental results is presented in Table 2.

Table 2.

Summary of the BBD experimental results for biodiesel production using the fou investigated catalysts.

\begin{tabular}{|c|c|c|c|c|}
\hline $\mathbf{S} / \mathbf{N}$ & Catalyst & $\begin{array}{l}\text { Synthesis } \\
\text { method }\end{array}$ & $\begin{array}{l}\text { Optimum } \\
\text { yield }(\%)\end{array}$ & Optimum conditions \\
\hline 1 & $\mathrm{Fe}-\mathrm{Co}-\mathrm{Ni} / \mathrm{MgO}$ & $\begin{array}{c}\text { Wet } \\
\text { impregnation }\end{array}$ & 92.2 & $\begin{array}{l}\text { MeOH: oil ratio }(15: 1 \mathrm{w} / \mathrm{w}), \\
\text { Catalyst }(15 \%, \mathrm{w} / \mathrm{w}) \text {, at } \\
55^{\circ} \mathrm{C} \text { and } 1 \mathrm{~h} .\end{array}$ \\
\hline 2 & $\mathrm{Fe}-\mathrm{Co}-\mathrm{Ni}-\mathrm{MgO}$ & $\begin{array}{l}\text { Green } \\
\text { synthesis }\end{array}$ & 97.9 & $\begin{array}{l}\text { MeOH: oil ratio }(15: 1 \mathrm{w} / \mathrm{w}) \text {, } \\
\text { Catalyst }(15 \% \mathrm{w} / \mathrm{w}) \text {, at } 55^{\circ} \mathrm{C} \\
\text { and } 1 \mathrm{~h} \text {. }\end{array}$ \\
\hline 3 & $\mathrm{Fe}-\mathrm{Co}-\mathrm{Ni} / \mathrm{ZnO}$ & $\begin{array}{c}\text { Wet } \\
\text { impregnation }\end{array}$ & 86.6 & $\begin{array}{l}\text { MeOH: oil ratio }(10: 1 \mathrm{w} / \mathrm{w}) \text {, } \\
\text { Catalyst }(10 \% \mathrm{w} / \mathrm{w}) \text {, at } 60^{\circ} \mathrm{C} \\
\text { and } 1 \mathrm{~h} \text {. }\end{array}$ \\
\hline 4 & $\mathrm{Fe}-\mathrm{Co}-\mathrm{Ni}-\mathrm{ZnO}$ & $\begin{array}{c}\text { Green } \\
\text { synthesis }\end{array}$ & 91.4 & $\begin{array}{l}\mathrm{MeOH} \text { : oil ratio }(15: 1 \mathrm{w} / \mathrm{w}) \text {, } \\
\text { Catalyst }(5 \% \mathrm{w} / \mathrm{w}) \text {, at } 55^{\circ} \mathrm{C} \\
\text { and } 3 \mathrm{~h} \text {. }\end{array}$ \\
\hline
\end{tabular}

The ANOVA for these experiments was used to generate regression models which are represented in Equations 4-7. The regression models show how the four reaction parameters; i.e., $\mathrm{MeOH}$ :oil molar ratio, temperature, time, and catalyst concentration, influenced biodiesel yield when each catalyst was employed.

$Y_{\mathrm{Fe}-\mathrm{Co}-\mathrm{Ni} / \mathrm{MgO}}=-2268.82+42.84 A+72.20 B+60.28 \mathrm{C}-6.92 \mathrm{D}-0.348 \mathrm{AB}-$ $1.855 A C-0.307 A D+0.245 B D-0.87 C D-0.545 A^{2}-0.623 B^{2}-8.05 C^{2}$

$Y_{\mathrm{Fe}-\mathrm{Co}-\mathrm{Ni}-\mathrm{MgO}}=-2894.69+18.25 \mathrm{~A}+100.10 \mathrm{~B}+26.96 \mathrm{C}-6.90 \mathrm{D}-$ $0.21 A B-1.08 A C-0.413 A D+0.28 B D-1.585 C D-0.88 B^{2}$

$Y_{F e-C O-N i / Z n O}=-1622.69+17.44 A+61.0 B-75.63 C-4.16 D-0.39 A B+$ $1.45 A C+0.478 A D-0.08 B C+1.455 C D-0.13 A^{2}-0.52 B^{2}+8.95 C^{2}-0.26 D^{2}$

(Eq. 6) 
$Y_{\mathrm{Fe}-\mathrm{Co}-\mathrm{Ni}-\mathrm{ZnO}}=-2147.98-15.4 A+69.8 B+197.38 \mathrm{C}-48.1 D+0.564 A B-$ $0.285 A C-0.38 A D-2.78 B C-0.693 B D-1.915 C D-0.37 A^{2}-0.6 B^{2}-6.28 C^{2}-$ $0.147 D^{2}$

where A is $\mathrm{MeOH}$ :oil molar ratio, B stands for temperature $\left({ }^{\circ} \mathrm{C}\right), \mathrm{C}$ is time (h), and D denotes catalyst concentration. The model equations were reliable, showing significant $(<0.05)$ model $p$-values of $0.0456,0.0094,0.0367$, and 0.0390 in Equations 4, 5, 6, and 7, respectively. The highest biodiesel yield of $97.9 \%$ was obtained with the green-synthesized $\mathrm{Fe}-\mathrm{Co}-\mathrm{Ni}-\mathrm{MgO}$ catalyst. It was also observed that both catalysts based on $\mathrm{MgO}$ support exhibited relatively higher catalytic performance compared to their $\mathrm{ZnO}$-based counterparts.

\subsection{Physicochemical properties and FAME profiles}

The FAME profiles of the $J$. curcas oil-based biodiesel products and their physicochemical properties were investigated in order to establish the effect of catalyst type on the quality/composition of the produced biodiesel. A summary of the FAME profiles of biodiesel products produced by various catalysts are presented in Table 3. As shown in Table 3, the biodiesel samples showed a total saturated fatty acid of $2.94-21.73 \%$ and total unsaturated fatty acid of $78.27-97.06 \%$. The high degree of unsaturation is typical feature of Jatropha of Jatropha biodiesel produced using the four catalysts are presented in Figures S9-12.

The Jatropha biodiesel obtained using the green-synthesized $\mathrm{Fe}-\mathrm{Co}-\mathrm{Ni}$ $\mathrm{MgO}$ contained unsaturated acid of oleic acid (78.27 wt \%), and saturated acids of n-hexadecanoic acid (12.14 wt\%), octadecanoic acid (6.87 wt\%), cyclohexanecarboxylic acid, undecyl ester (2.72 wt $\%)$. The total percentage composition of FAMEs was greater than the minimum FAME requiremen of $96.5 \%$ specified by the ASTM (Fig. 7). Overall, the product produced by $\mathrm{Fe}-\mathrm{Co}-\mathrm{Ni}-\mathrm{MgO}$ catalyst consisted of $78.27 \%$ unsaturated and $21.73 \%$ saturated fatty acids (Fig. 8). Hence, the biodiesel obtained using this greensynthesized catalyst resulted in the highest yield and the lowest degree of unsaturation in spite of the fact that high degree of unsaturation is a general characteristic of Jatropha biodiesels (Mofijur et al., 2017).

The Jatropha biodiesel produced from the wet impregnation-prepared $\mathrm{Fe}-\mathrm{Co}-\mathrm{Ni} / \mathrm{ZnO}$ catalyst consisted of $88.9 \%$ unsaturated and $11.1 \%$ saturated fatty acids (Fig. 8). This indicates that the catalyst produced a low-grade biodiesel, since the higher the percentage of unsaturated fatty acids in biodiesel, the lower its oxidative and thermal stability would be. In another words, this denotes that the resultant biodiesel would deteriorate faster in high-temperature environments. The biodiesel produced by greensynthesized $\mathrm{Fe}-\mathrm{Co}-\mathrm{Ni}-\mathrm{ZnO}$ catalyst contained $8.74 \mathrm{wt} \%$ n-haxadacanoic acid, $81.4 \mathrm{wt} \%$ oleic acid, $7.71 \mathrm{wt} \%$ octadecanoic acid, and $2.51 \mathrm{wt} \%$

Table 3.

FAME compositions of the biodiesel products by various catalysts.

\begin{tabular}{|c|c|c|c|c|}
\hline Catalyst & $\mathbf{R T}^{\mathbf{a}}$ & Methyl ester & $\begin{array}{l}\text { Molecular } \\
\text { formula }\end{array}$ & Composition (\%) \\
\hline \multirow{2}{*}{$\begin{array}{l}\mathrm{Fe}-\mathrm{Co}-\mathrm{Ni} / \mathrm{MgO} \\
\text { (Wet Impregnation) }\end{array}$} & 38.737 & Oleic acid, 9-Octadecenoic acid, cis-Vaccenic acid & $\mathrm{C}_{19} \mathrm{H}_{36} \mathrm{O}_{2}$ & 97.06 \\
\hline & 43.959 & $\begin{array}{l}\text { Cyclohexanecarboxylic acid, pentadecyl ester; Docosanoic acid,4,4-dimethyl-ester; } \\
\text { Adipic acid,butyl 2-pentylester }\end{array}$ & $\mathrm{C}_{22} \mathrm{H}_{42} \mathrm{O}_{2}$ & 2.94 \\
\hline \multirow{4}{*}{$\begin{array}{l}\mathrm{Fe} \text {-Co-Ni-MgO } \\
\text { (Green Synthesis) }\end{array}$} & 35.555 & $\begin{array}{l}\text { n-Hexadecanoic acid } \\
\mathrm{AN}^{\mathrm{d}}: \text { palmitic acid }\end{array}$ & $\begin{array}{l}\mathrm{C}_{16} \mathrm{H}_{32} \mathrm{O}_{2} \\
\left(\text { Sat. }^{\mathrm{b}}\right)\end{array}$ & 12.14 \\
\hline & 39.037 & $\begin{array}{l}\text { 6-Octadecanoic acid, } \\
\text { 9-Octadecanoic acid, } \\
\text { (E) - Oleic acid }\end{array}$ & $\begin{array}{l}\mathrm{C}_{18} \mathrm{H}_{34} \mathrm{O}_{2} \\
\left(\text { Unsat. }^{\mathrm{c}} \text { ) }\right.\end{array}$ & 78.27 \\
\hline & 39.276 & $\begin{array}{l}\text { Octadecanoic acid } \\
\text { AN: Stearic acid }\end{array}$ & $\begin{array}{l}\mathrm{C}_{17} \mathrm{H}_{35} \mathrm{COOH} \\
\text { (Sat.) }\end{array}$ & 6.87 \\
\hline & 43.971 & $\begin{array}{l}\text { Cyclohexanecarboxylic acid, undecyl ester; } \\
\text { Cyclohexanecarboxylic acid, heptyl ester; Adipic acid, butyl 2-pentyl ester } \\
\text { AN: Undecyl cyclohexanecarboxylate }\end{array}$ & $\begin{array}{l}\mathrm{C}_{18} \mathrm{H}_{34} \mathrm{O}_{2} \\
\text { (Sat.) }\end{array}$ & 2.72 \\
\hline \multirow{6}{*}{$\begin{array}{l}\mathrm{Fe}-\mathrm{Co}-\mathrm{Ni} / \mathrm{ZnO} \\
\text { (Wet Impregnation) }\end{array}$} & 20.872 & $\begin{array}{l}\text { Cyclohexasiloxane, dodecamethyl-cyclohexasiloxane, dodecamethyl-5-[4- } \\
\text { (Dimethylamino) benzylideneamino]-2-phenyl-2H-benzotriazole }\end{array}$ & $\mathrm{C}_{12} \mathrm{H}_{36} \mathrm{O}_{6} \mathrm{Si}_{6}$ (Sat.) & 3.32 \\
\hline & 25.221 & $\begin{array}{l}\text { N-benzyl-N-ethyl-p-isopropylbenzamide, pentasiloxane, dodecamethyl-4H-1,2,4- } \\
\text { Triazole-3-thiol, 4-allyl-5-(1-naphthylmethyl)- }\end{array}$ & $\begin{array}{l}\mathrm{C}_{19} \mathrm{H}_{23} \mathrm{NO} \\
\text { (Unsat.) }\end{array}$ & 8.25 \\
\hline & 29.115 & $\begin{array}{l}\text { Silane,[[4-[1,2-bis[(trimethylsilyl)oxy]ethyl]-1,2-phenylene]bis(oxy)]bis[trimethyl- } \\
\text { Silane,[[4-[1,2-bis[(trimethylsilyl)oxy]ethyl]-1,2-phenylene]bis(oxy]bis[trimethyl- } \\
\text { Cyclopentasiloxane, decamethyl }\end{array}$ & $\mathrm{C}_{10} \mathrm{H}_{30} \mathrm{Si}_{5}$ (Sat.) & 4.77 \\
\hline & 36.979 & $\begin{array}{l}\text { 13-Hexyloxacyclotridec-10-en-2-one } \\
\text { Bicylco[2.2.1] heptan-2-one, 3-(2-oxopropyl)-, exo- } \\
\text { Bicylco(5.3.1) undecan-11-one }\end{array}$ & $\begin{array}{l}\mathrm{C}_{11} \mathrm{H}_{18} \mathrm{O} \\
\text { (Sat.) }\end{array}$ & 3.01 \\
\hline & 37.697 & $\begin{array}{l}\text { 9-octadecenoic acid (Z)-, methyl ester } \\
\text { 15-octadecenoic acid, methyl ester } \\
\text { 9-octadecenoic acid, methyl ester }\end{array}$ & $\mathrm{C}_{18} \mathrm{H}_{34} \mathrm{O}_{2}$ (Unsat.) & 3.06 \\
\hline & 38.648 & $\begin{array}{l}\text { cis-13-octadecenoic acid } \\
\text { cis-vaccenic acid } \\
9,12 \text {-octadacadienoic } \operatorname{acid}(\mathrm{z}, \mathrm{z})\end{array}$ & $\mathrm{C}_{18} \mathrm{H}_{34} \mathrm{O}_{2}$ (Unsat.) & 77.59 \\
\hline \multirow{4}{*}{$\begin{array}{l}\mathrm{Fe}-\mathrm{Co}-\mathrm{Ni}-\mathrm{ZnO} \\
\text { (Green Synthesis) }\end{array}$} & 35.489 & n-Hexadecanoic acid & $\mathrm{C}_{16} \mathrm{H}_{32} \mathrm{O}_{2}$ & 8.74 \\
\hline & 38.982 & $\begin{array}{l}\text { Oleic acid } \\
\text { 6-octadecanoic acid } \\
\text { 9-octadecanoic acid }\end{array}$ & $\mathrm{C}_{18} \mathrm{H}_{34} \mathrm{O}_{2}$ & 81.04 \\
\hline & 39.221 & Octadecanoic acid & $\mathrm{C}_{18} \mathrm{H}_{36} \mathrm{O}_{2}$ & 7.71 \\
\hline & 43.960 & Cyclohexanecarboxylic acid, undecyl ester & $\mathrm{C}_{15} \mathrm{H}_{28} \mathrm{O}_{2}$ & 2.51 \\
\hline
\end{tabular}

${ }^{\mathrm{a}}$ RT: Retention time; ${ }^{\mathrm{b}}$ Sat.: Saturated; ${ }^{\mathrm{c}}$ Unsat.: Unsaturated; ${ }^{\mathrm{d}}$ AN: Another name 


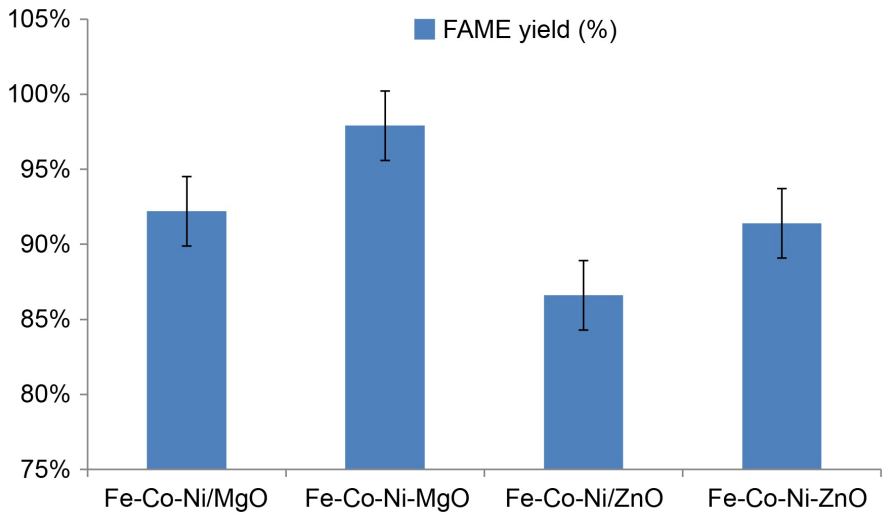

Fig. 7. FAME yield (\%) of the four catalysts used.

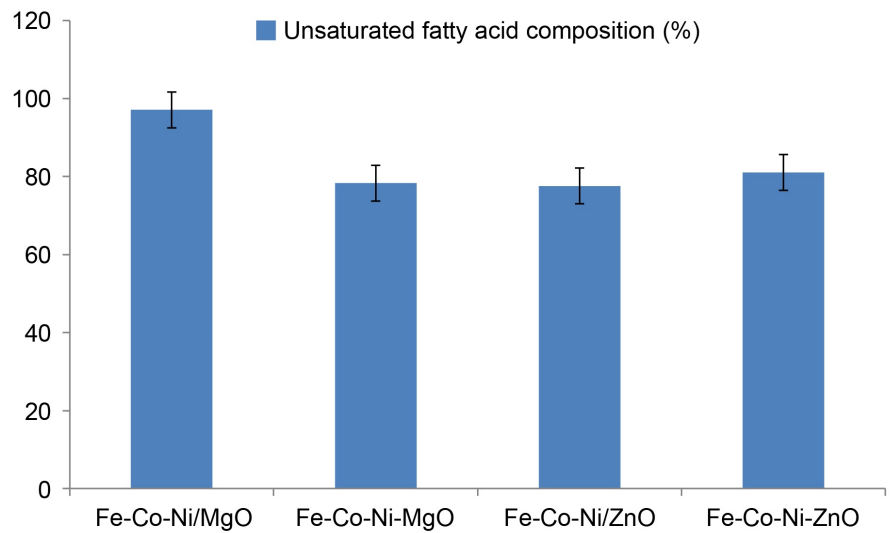

Fig. 8. The composition of unsaturated fatty acids in the biodiesels produced using the four catalysts.

cyclohexanecarboxylic acid undecyl ester (Fig. 8). The maximum FAME conversion achieved using this catalyst stood at $81.04 \%$ (Fig. 7) with oleic acid as the most abundant FAME. Moreover, the FAME profile consisted of $81.04 \%$ unsaturated and $18.96 \%$ saturated fatty acids. Overall, apart from the major influence of Jatropha oil used as feedstock, the catalysts prepared either by the wet impregnation or green synthesis methods were shown to affect the FAME compositions of the final biodiesel products. It is however interesting to note that the combined influence of $\mathrm{MgO}$ as support material and the green synthesis
Table 4.

Comparison of the FAME yield of $\mathrm{Fe}-\mathrm{Co}-\mathrm{Ni}-\mathrm{MgO}$ with the other solid catalysts used for biodiesel production reported in the literature.

\begin{tabular}{lllcl}
\hline S/N & Catalyst & Synthesis method & $\begin{array}{c}\text { FAME } \\
\text { Yield (\%) }\end{array}$ & Reference \\
\hline 1 & $\begin{array}{l}\text { Magnetic } \\
\text { core-shell } \\
\mathrm{SO}_{4} / \mathrm{Mg}-\mathrm{Al}-\mathrm{Fe}_{3} \mathrm{O}_{4}\end{array}$ & $\begin{array}{l}\text { Stepwise co-precipitation, } \\
\text { encapsulation, and surface } \\
\text { functionalization }\end{array}$ & 98.5 & $\begin{array}{l}\text { Gardy et al. } \\
(2019)\end{array}$ \\
\hline & $\begin{array}{l}\text { Rg/Al/Zn-based } \\
\text { hydrotalcite/SBA- }\end{array}$ & $\begin{array}{l}\text { Rational design using a } \\
\text { versatile } \text { in situ } \text { method } \\
\text { including synthesis of } \\
\text { macroporous hydrotalcite- } \\
\text { derived oxides comprising } \\
\text { ordered silica architectures }\end{array}$ & 90 & $\begin{array}{l}\text { Prabu et al. } \\
(2019)\end{array}$ \\
3 & Fe-Co-Ni-MgO & Green synthesis & 97.9 & Present Study \\
\hline
\end{tabular}

Table 5.

Physicochemical properties of biodiesel produced by the four different catalysts, i.e., (a) $\mathrm{Fe}$ $\mathrm{Co}-\mathrm{Ni} / \mathrm{MgO}$, (b) $\mathrm{Fe}-\mathrm{Co}-\mathrm{Ni}-\mathrm{MgO}$, (c) $\mathrm{Fe}-\mathrm{Co}-\mathrm{Ni} / \mathrm{ZnO}$, and (d) $\mathrm{Fe}-\mathrm{Co}-\mathrm{Ni}-\mathrm{ZnO}$.

\begin{tabular}{lccccc}
\hline Fuel properties & (a) & (b) & (c) & (d) & ASTM standard \\
\hline $\begin{array}{l}\text { Density at } 15^{\circ} \mathrm{C}\left(\mathrm{g} / \mathrm{cm}^{3}\right) \\
\text { Kinematic viscosity at } 40\end{array}$ & 0.882 & 0.8673 & 0.886 & 0.866 & $0.860-0.900^{1}$ \\
$\begin{array}{l}{ }^{\circ} \mathrm{C}\left(\mathrm{mm}^{2} / \mathrm{s}\right) \\
\text { Flash point }\left({ }^{\circ} \mathrm{C}\right)\end{array}$ & - & 2.31 & - & - & $1.9-6.0^{2}$ \\
Cloud point $\left({ }^{\circ} \mathrm{C}\right)$ & -8 & 2 & 10 & -2 & $-3-12^{4}$ \\
Pour point $\left({ }^{\circ} \mathrm{C}\right)$ & 2 & -10 & -4 & -15 & $-15-10^{5}$ \\
Fire Point $\left({ }^{\circ} \mathrm{C}\right)$ & 193 & 148 & 223 & 230 & $\geq 130^{6}$ \\
Acid value $(\mathrm{mg} \mathrm{KOH} / \mathrm{g})$ & 0.4039 & 0.59466 & 0.5553 & 0.4544 & $\leq 0.80^{7}$ \\
FFA concentration $(\mathrm{wt} \%)$ & - & 0.5428 & 0.5069 & 0.4148 & - \\
\hline
\end{tabular}

${ }^{1}$ ASTM D $1298,{ }^{2}$ ASTM D445, ${ }^{3}$ ASTM D92, ${ }^{4}$ ASTM D2500, ${ }^{5}$ ASTM D97, ${ }^{6}$ ASTM D92 ${ }^{7}$ ASTM D664

route as catalyst preparation technique (i.e., using green-synthesized $\mathrm{Fe}$ $\mathrm{Co}-\mathrm{Ni}-\mathrm{MgO}$ catalyst) resulted in the most favorable outcomes both quantitatively and qualitatively in comparison with the application of the three catalysts. A comparison of the highest FAME yield obtained in the current study (i.e., for $\mathrm{Fe}-\mathrm{Co}-\mathrm{Ni}-\mathrm{MgO}$ ) and those reported in the most recen literature is presented in Table 4.

Physicochemical properties of the biodiesels produced by the catalysts $v s$. the ASTM standard values are tabulated in Table 5 and Figure 9; confirming the acceptable quality of the products while also revealing considerable differences among them depending on the catalyst employed.

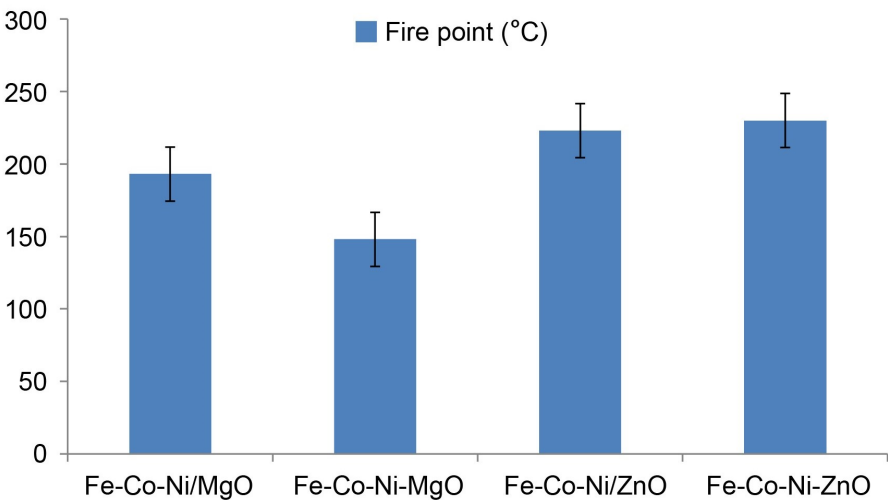

Fig. 9. The acid value, fire point, density at $15^{\circ} \mathrm{C}$, flash point, FFA\%, cloud point, and pour point of the biodiesels produced by using the different catalysts. 

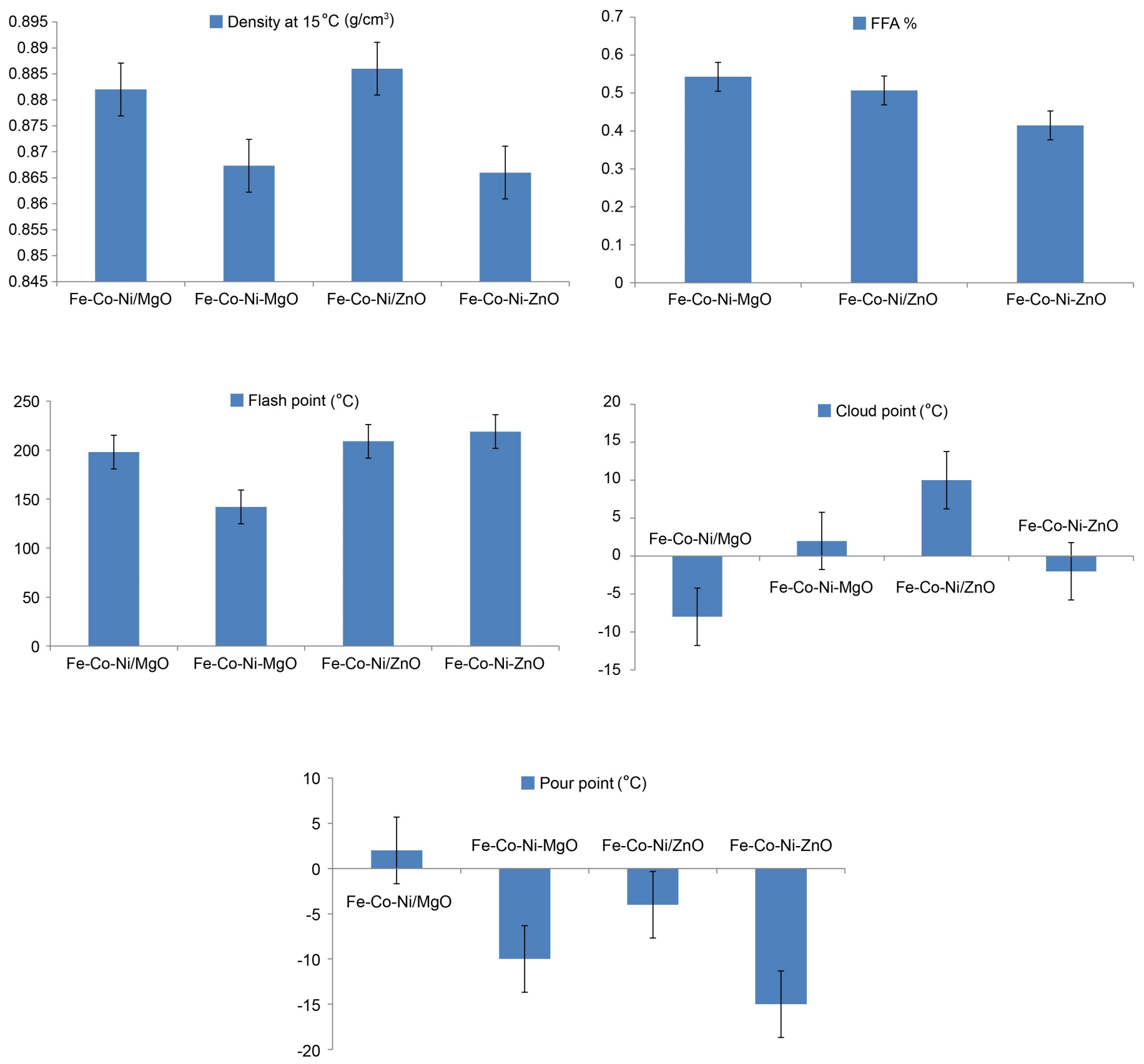

Fig. 9. continued.

\section{Conclusions}

The effects of green synthesis (using leaf extracts) and wet impregnation methods for the preparation of catalysts along with different support materials, on yield, composition, and properties of Jatropha biodiesel were investigated. As for the catalyst properties, the green-synthesized heterogeneous tri-metallic catalysts appeared more bespoke in morphology, but exhibited lower thermal stability. Irrespective of the method of synthesis, the crystalline phases revealed by the XRD and the FTIR spectra of the catalysts were dependent on the catalyst support material $(\mathrm{MgO}$ or $\mathrm{ZnO})$. Moreover, the findings obtained revealed that catalyst type could determine FAME profile of the biodiesel produced from the same oil feedstock. More specifically, the support material used and the method employed for catalyst synthesis influenced the type of methyl esters found in the final biodiesel product. Higher yield was obtained with magnesium oxide as support material than with zinc oxide, and higher yields were obtained with green-synthesized catalysts 
compared with their counterparts synthesized through wet impregnation.

\section{Acknowledgements}

The authors wish to acknowledge the Department of Chemical Engineering, University of Ilorin, Nigeria, for permitting the use of laboratory facilities especially the GC-MS equipment.

\section{References}

[1] Abdulkareem, A.S., Kariim, I., Bankole, M.T., Tijani, J.O., Abodunrin, T.F., Olu, S.C., 2017. Synthesis and Characterization of tri-metallic FeCo-Ni catalyst supported on $\mathrm{CaCO}_{3}$ for multi-walled carbon nanotubes growth via chemical vapor deposition technique. Arabian J. Sci. Eng. 42(10), 4365-4381

[2] Al-Muhtaseb, A.H., Jamil, F., Al-Haj, L., Myint, M.T.Z., Mahmoud, E., Ahmad, M.N., Hasan, A.O., Rafiq, S., 2018. Biodiesel production over a catalyst prepared from biomass-derived waste date pits. Biotechnol. Rep. 20, e00284

[3] Andronie, L., Coroiani, A., Miresani, V., Pop, I., Raducu, C., Odagiu, A., Marchuș, Z., Coroiani C., 2017. Vibrational study for the lemon and tangerine fruit using FT-IR spectroscopy. ProEnvironment/ProMediu. 10(31), 221-224

[4] Altun S., 2014. Effect of the degree of unsaturation of biodiesel fuels on the exhaust emissions of a diesel power generator. Fuel. 117, 450-457.

[5] Banerjee, M., Dey, B., Talukdar, J., Kalita, M.C., 2014. Production of biodiesel from sunflower oil using highly catalytic bimetallic gold-silver core-shell nanoparticle. Energy. 69, 695-699.

[6] Benjumea, P., Agudelo, J.R., Agudelo, A.F., 2010. Effect of the degree of unsaturation of biodiesel fuels on engine performance, combustion characteristics, and emissions. Energy Fuels. 25(1), 77-85.

[7] Cruz-Ortiz, B.R., Ríos-González, L.J., 2017. Influence of the reaction parameters on biodiesel production catalyzed by a lipase from Thermomyces lanuginosus immobilized in PVA-alginate beads. Energy Sources Part A. 39(23), 2127-2132.

[8] Das, R.K., Gogoi, N., Babu, P.J., Sharma, P., Mahanta, C., Bora, U., 2012. The synthesis of gold nanoparticles using amaranthus spinosus leaf extract and study of their optical properties. Adv. Mater. Phys. Chem. 2(4), 275-281.

[9] De, S., Zhang, J., Luque, R., Yan, N., 2016. Ni-based bimetallic heterogeneous catalysts for energy and environmental applications. Energy Environ. Sci. 9(11), 3314-3347

[10] Farooq, M., Ramli, A., Naeem, A., 2016. Effect of different metal oxides on the catalytic activity of $\gamma-\mathrm{Al}_{2} \mathrm{O}_{3}-\mathrm{MgO}$ supported bifunctional heterogeneous catalyst in biodiesel production from WCO. RSC Adv. 2016, 6(2), 872-881

[11] Folayan, A.J., Anawe, P.A.L., Aladejare, A.E., Ayeni, A.O., 2019. Experimental investigation of the effect of fatty acids configuration, chain length, branching and degree of unsaturation on biodiesel fuel properties obtained from lauric oils, high-oleic and high-linoleic vegetable oil biomass. Energy Rep. 5, 793-806.

[12] Gardy, J., Nourafkan, E., Osatiashtiani, A., Lee, A.F., Wilson, K., Hassanpour, A., Lai, X., 2019. A core-shell $\mathrm{SO}_{4} / \mathrm{Mg}-\mathrm{Al}-\mathrm{Fe}_{3} \mathrm{O}_{4}$ catalyst for biodiesel production. Appl. Catal., B. 259, 118093

[13] Gardy, J., Osatiashtiani, A., Céspedes, O., Hassanpour, A., Lai, X., Lee, A.F., Wilson, K., Rehan, M., 2010. A magnetically separable $\mathrm{SO}_{4} / \mathrm{Fe}-\mathrm{Al}-$ $\mathrm{TiO}_{2}$ solid acid catalyst for biodiesel production from waste cooking oil. Appl. Catal., B. 234, 268-278.

[14] Gopinath, A., Puhan, S., Nagarajan, G., 2010. Effect of unsaturated fatty acid esters of biodiesel fuels on combustion, performance and emission characteristics of a DI diesel engine. Int. J. Energy Environ. 1(3), 411430

[15] Gupta, J., Agarwal, M., 2016. Preparation and characterizaton of $\mathrm{CaO}$ nanoparticle for biodiesel production. AIP Conf. Proc. 1724(1), 020066.

[16] Hellier, P., Talibi, M., Eveleigh, A., Ladommatos, N., 2017. An overview of the effects of fuel molecular structure on the combustion and emissions characteristics of compression ignition engines. Proc. Inst. Mech. Eng., D. 232(1), $90-105$.
[17] Kaisan, M.U., Anafi, F.O., Nuszkwoski, J., Kulla D.M., Umaru, S. 2016. GC/MS analysis of methyl esters of biodiesel produced from cotton seed oil. Niger. J. Sol. Energy. 27, 56-61.

[18] Kalz, K.F., Kraehnert, R., Dvoyashkin, M., Dittmeyer, R., Glaser, R. Krewer, U., Reuter, K., Grunwaldt, J.D., 2017. Future challenges in heterogeneous catalysis: understanding catalysts under dynamic reaction conditions. ChemCatChem. 9(1), 17-29.

[19] Kamal, N.B.T.M., 2018. Preparation, characterization and mechanistic study of alumina supported calcium oxide based catalysts in transesterification of refined cooking oil. $\mathrm{PhD}$ Thesis, Universiti Teknologi Malaysia, Malaysia.

[20] Kwong, T., Yung, K., 2015. Heterogeneous alkaline earth metaltransition metal bimetallic catalysts for synthesis of biodiesel from low grade unrefined feedstock. RSC Adv. 5(102), 83748-83756.

[21] Lapuerta, M., Armas, O., Rodríguez-Fernández, J., 2009. Effect of the Degree of Unsaturation of Biodiesel Fuels on $\mathrm{NO}_{\mathrm{x}}$ and Particulate Emissions. SAE Int. J. Fuels Lubr. 1(1), 1150-1158.

[22] Mofijur, M., Rasul, M.G., Hassan, N.M.S., Masjuki, H.H., Kalam, M.A., Mahmudul, H.M., 2017. Chapter fourteen - assessment of physical, chemical, and tribological properties of different biodiesel Fuels. Clean Energy Sust. Dev. 441-463.

[23] Muthukumar, H., Matheswaran, M., 2015. Amaranthus spinosus leaf extract mediated $\mathrm{FeO}$ nanoparticles: physicochemical traits, photocatalytic and antioxidant activity. ACS Sust. Chem. Eng. 3(12) 3149-3156

[24] Nasar, M., Taufiq-Yap, Y.H., 2017. Synthesis and characterization of solid heterogeneous catalyst for the production of biodiesel from high FFA waste cooking oil. Bayer. J. Pure Appl. Sci. 10(1), 62-66.

[25] Omotoso, M., Ayodele, M., Akintudire, A., 2011. Comparative Study of the properties of biodiesel prepared from Jatropha curcas oil and palm oil. Global Res. J. 1(1), 1-13.

[26] Prabu, M., Manikandan, M., Kandasamy, P., Kalaivani, P.R. Rajendiran, N., Raja, T., 2019. Synthesis of Biodiesel using the $\mathrm{Mg} / \mathrm{Al} / \mathrm{Zn}$ Hydrotalcite/SBA-15 Nanocomposite Catalyst. ACS Omega. 4(2), 3500-3507.

[27] Refaat, A.A., 2009. Correlation between the chemical structure of biodiesel and its physical properties. Int. J. Environ. Sci. Technol 6(4), 677-694.

[28] Sharma, S., Saxena, V., Baranwal, A., Chandra, P., Pandey, L.M., 2018. Engineered nanoporous materials mediated heterogeneous catalysts and their implications in biodiesel production. Mater. Sci. Energy Technol. 1(1), 11-21.

[29] Sharmila, S., Rebecca, L.J., Anbuselvi, S., Kowsalya, E., Kripanand, N.R., 2016. GC-MS Analysis of biofuel extracted from marine algae. Der Pharmacia Lett. 8(3), 204-214.

[30] Sokoto, M.A., Hassan, L.G., Dangoggo, S.M., Ahmad, H.G., Uba, A., 2011. Influence of fatty acid methyl esters on fuel properties of biodiesel produced from the seeds oil of Curcubita pepo. Niger. J. Basic Appl. Sci. 19(1), 81-86

[31] Sutapa, I. W., Wahab, A.W., Taba, P., Nafie, N., 2018. Synthesis and structural profile analysis of the $\mathrm{MgO}$ nanoparticles produced through the sol-gel method followed by annealing process. Orient. J. Chem. 34(2), 1016-1025

[32] Tsai, C., 2017. Rational design of heterogeneous catalysts from first principles. PhD Thesis, Stanford University, California.

[33] Wang, Z., Hu, P., 2016. Towards rational catalyst design: a genera optimization framework. Philos. Trans. R. Soc. London, Ser. A. 374(2061), 20150078

[34] Yang, J., Astatkie, T., He, Q.S., 2016. A comparative study on the effect of unsaturation degree of camelina and canola oils on the optimization of bio-diesel production. Energy Rep. 2, 211-217.

[35] Yang, R., Du, X., Zhang, X., Xin, H., Zhou, K., Li, D., Hu, C., 2019. Transformation of Jatropha Oil into High-Quality Biofuel over Ni-W Bimetallic Catalysts. ACS Omega. 4(6), 10580-10592.

[36] Yin, W., Venderbosch, R.H., He, S., Bykova, M.V., Khromova, S.A., Yakovlev, V.A., Heeres, H.J., 2017. Mono-, bi-, and tri-metallic Nibased catalysts for the catalytic hydrotreatment of pyrolysis liquids. Biomass Convers. Biorefin. 7(3), 361-376. 


\section{Supplementary Data}

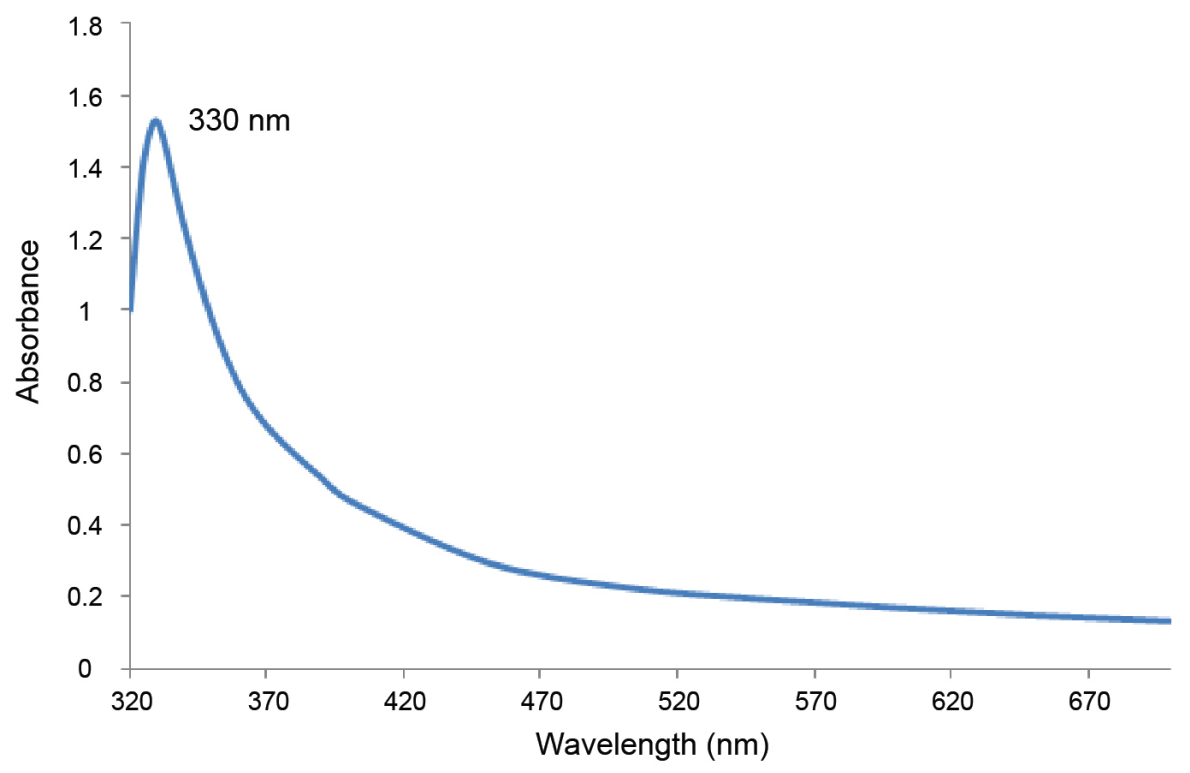

Fig. S1. FTIR spectrum of Amaranthus spinosus leaf extract.

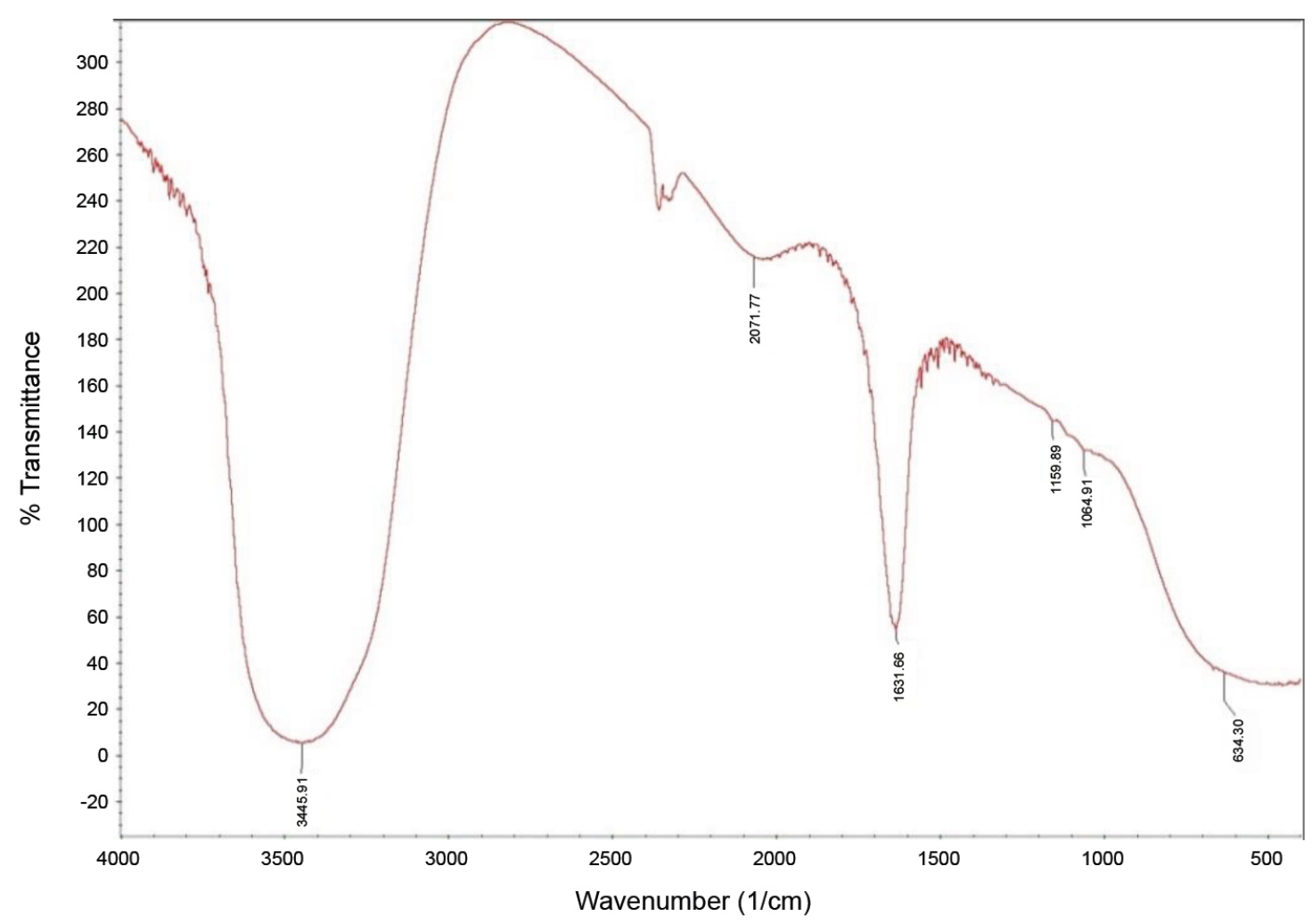

Fig. S2. UV-Vis spectrum of colloidal $\mathrm{MgO}$ nanoparticles 


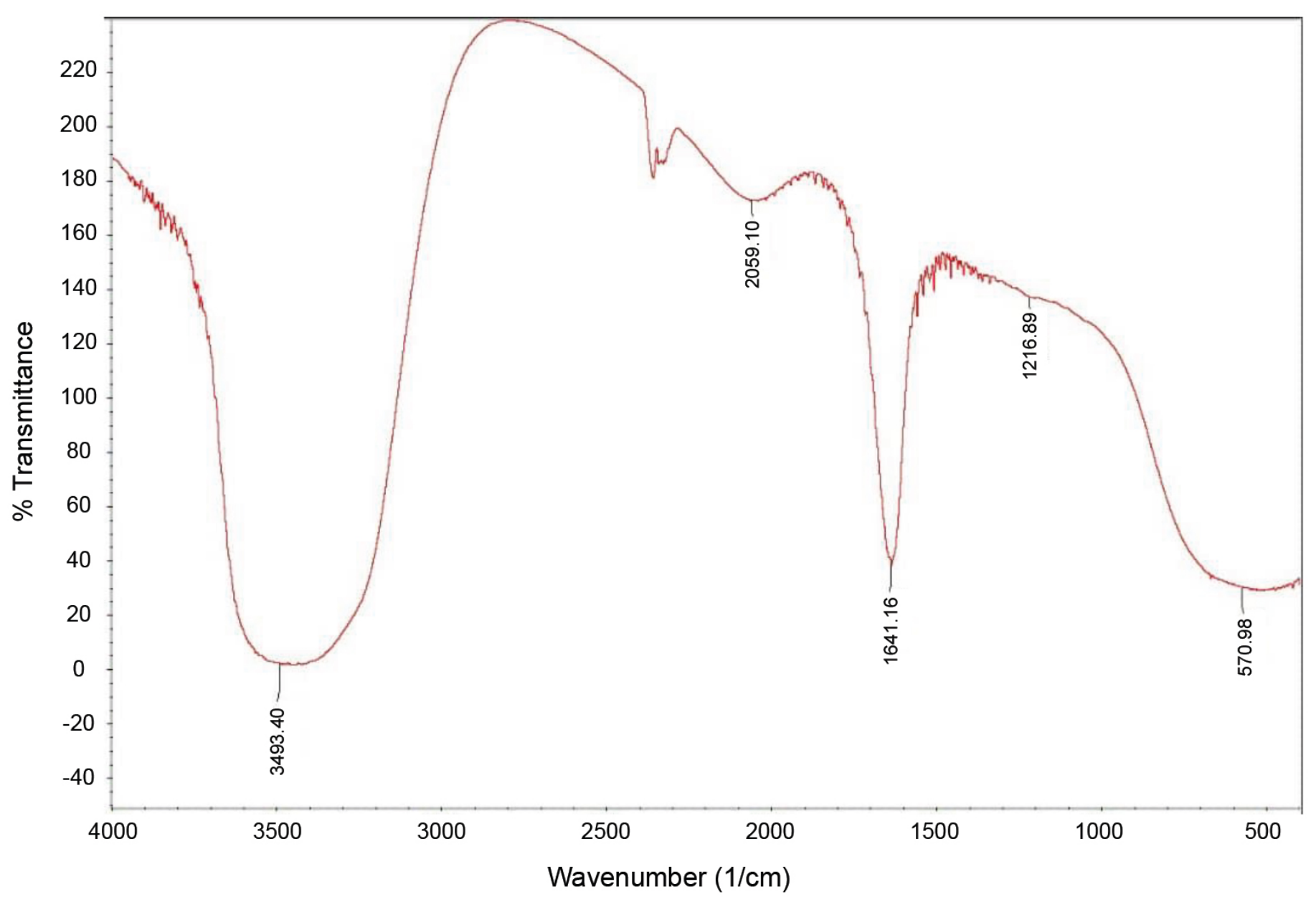

Fig. S3. FTIR spectrum of Citrus aurantifolia leaf extract. 

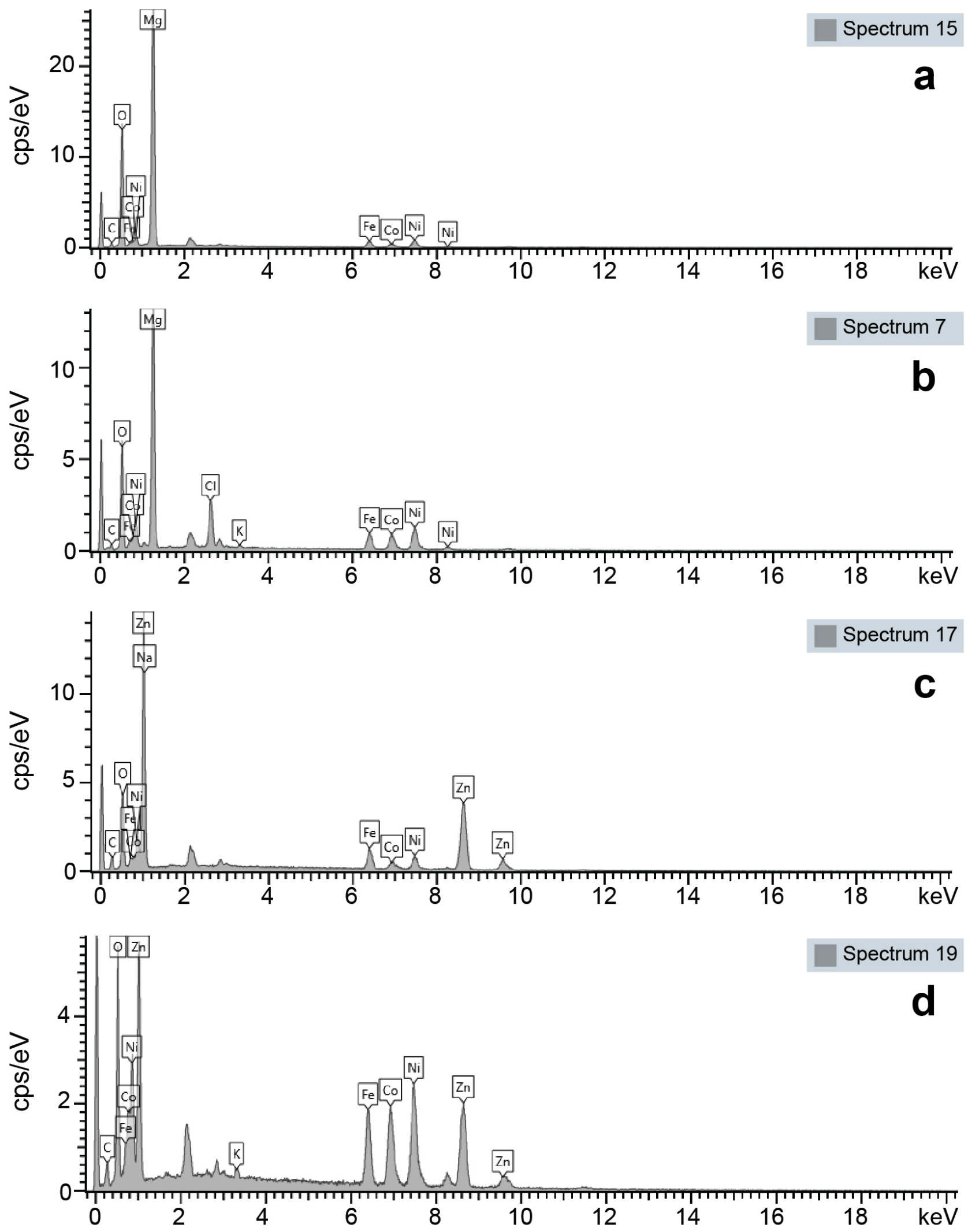

Fig. S4. The EDS analysis of different catalysts; (a) $\mathrm{Fe}-\mathrm{Co}-\mathrm{Ni} / \mathrm{MgO}$, (b) $\mathrm{Fe}-\mathrm{Co}-\mathrm{Ni}-\mathrm{MgO}$, (c) $\mathrm{Fe}-\mathrm{Co}-\mathrm{Ni} / \mathrm{ZnO}$, and (d) $\mathrm{Fe}-\mathrm{Co}-\mathrm{Ni}-\mathrm{ZnO}$. 


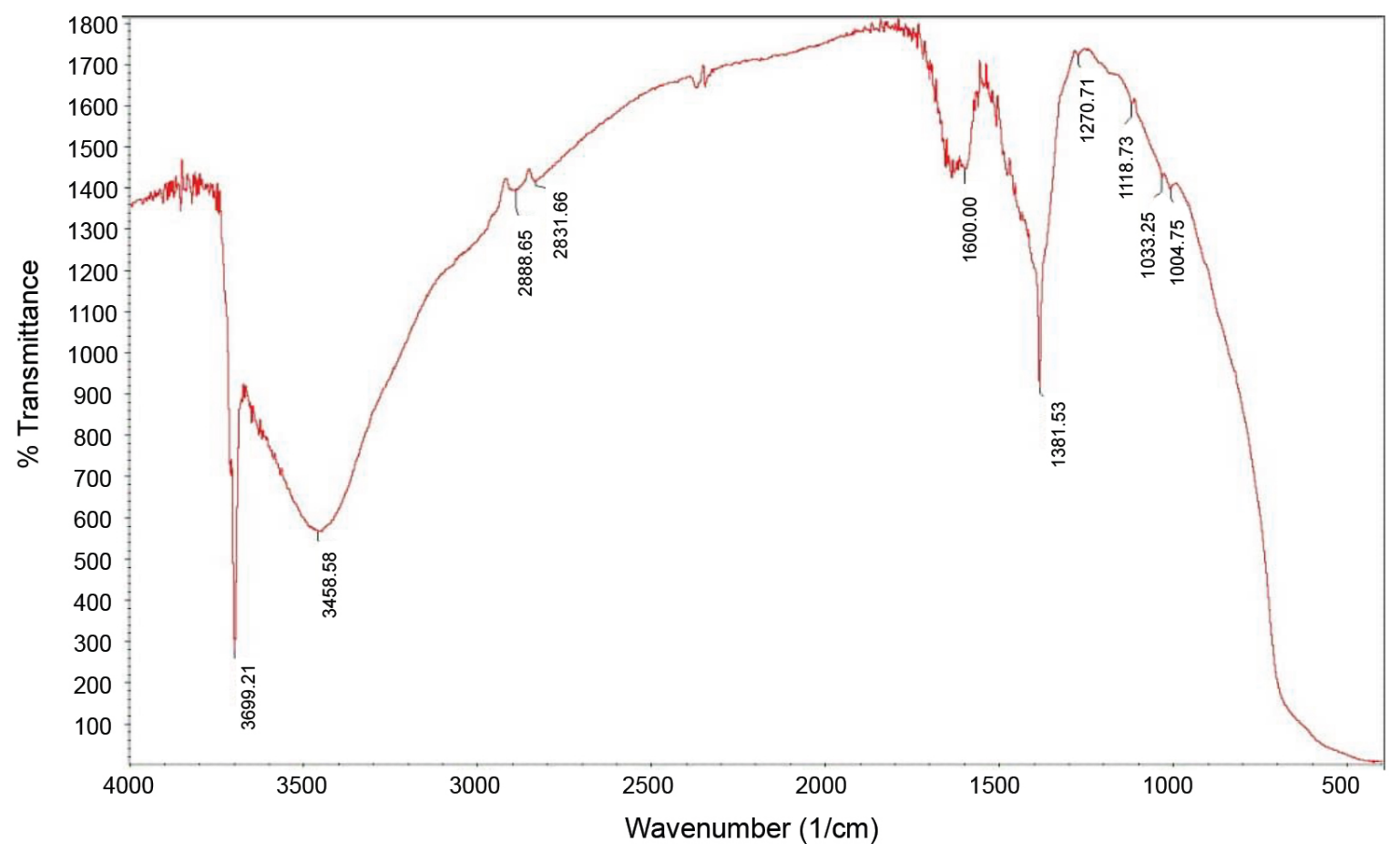

Fig. S5. FTIR spectrum of $\mathrm{Fe}-\mathrm{Co}-\mathrm{Ni} / \mathrm{MgO}$ catalyst.

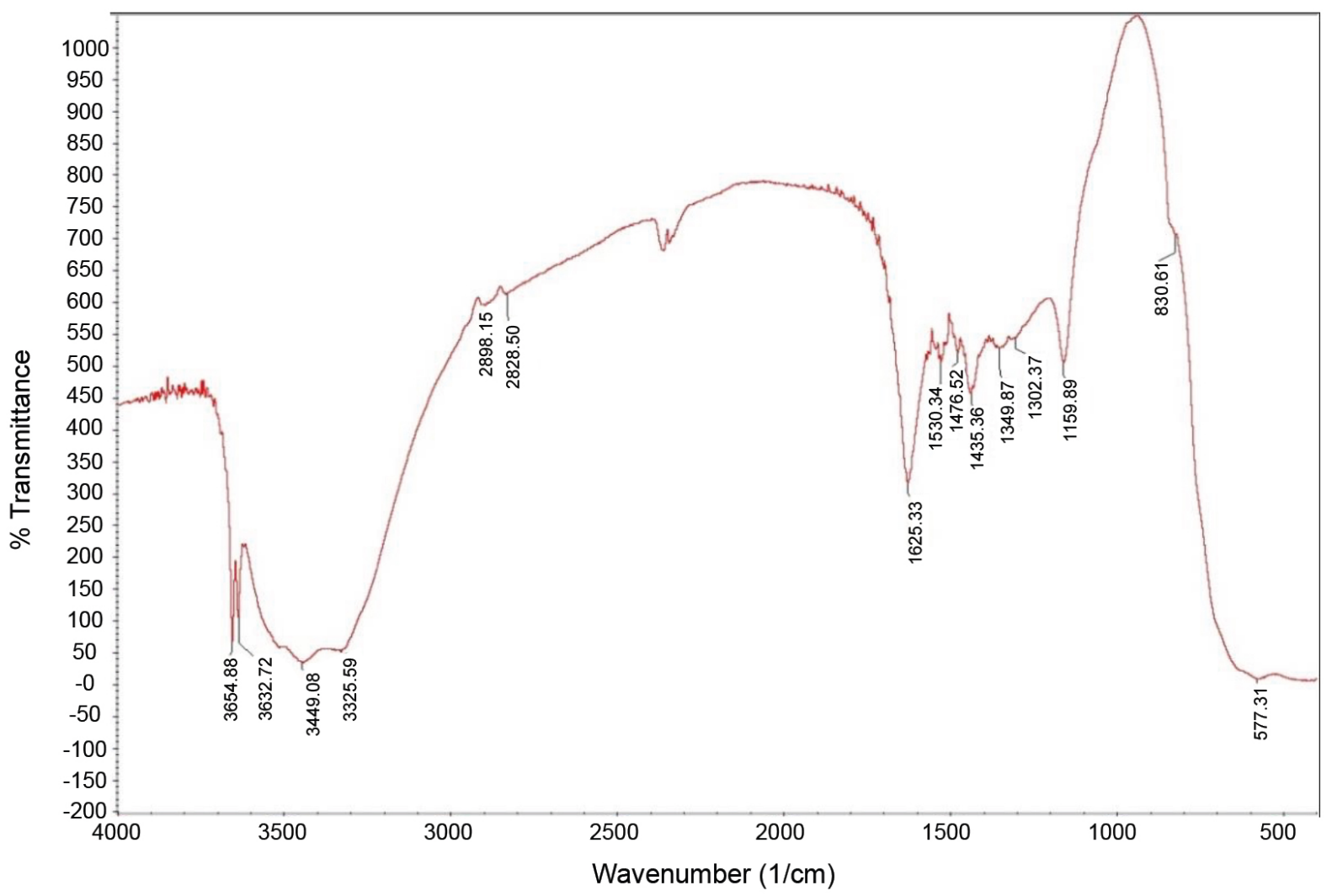

Fig. S6. FTIR spectrum of $\mathrm{Fe}-\mathrm{Ni}-\mathrm{Co}-\mathrm{MgO}$ catalyst. 


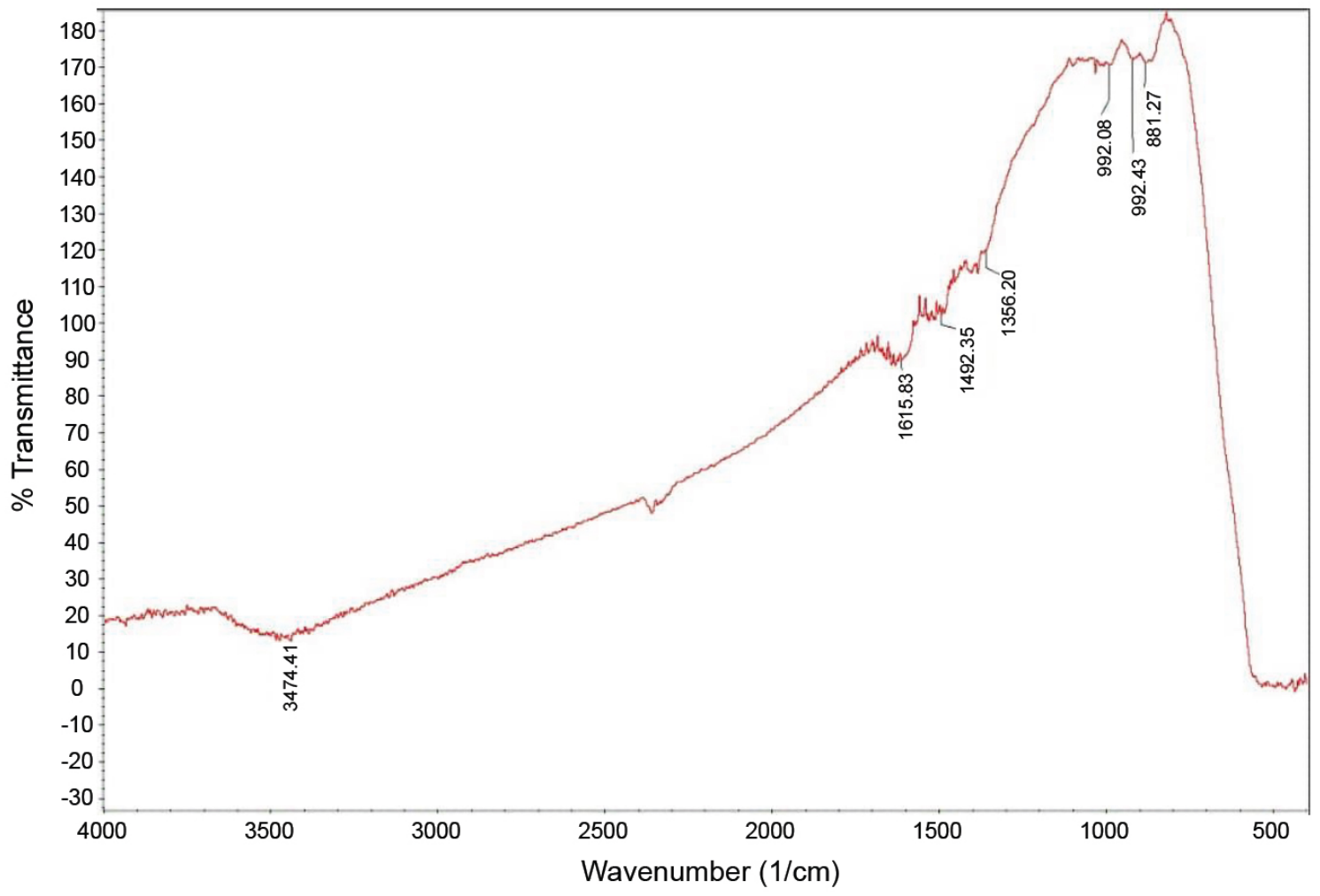

Fig. S7. FTIR spectrum of $\mathrm{Fe}-\mathrm{Co}-\mathrm{Ni} / \mathrm{ZnO}$ catalyst.

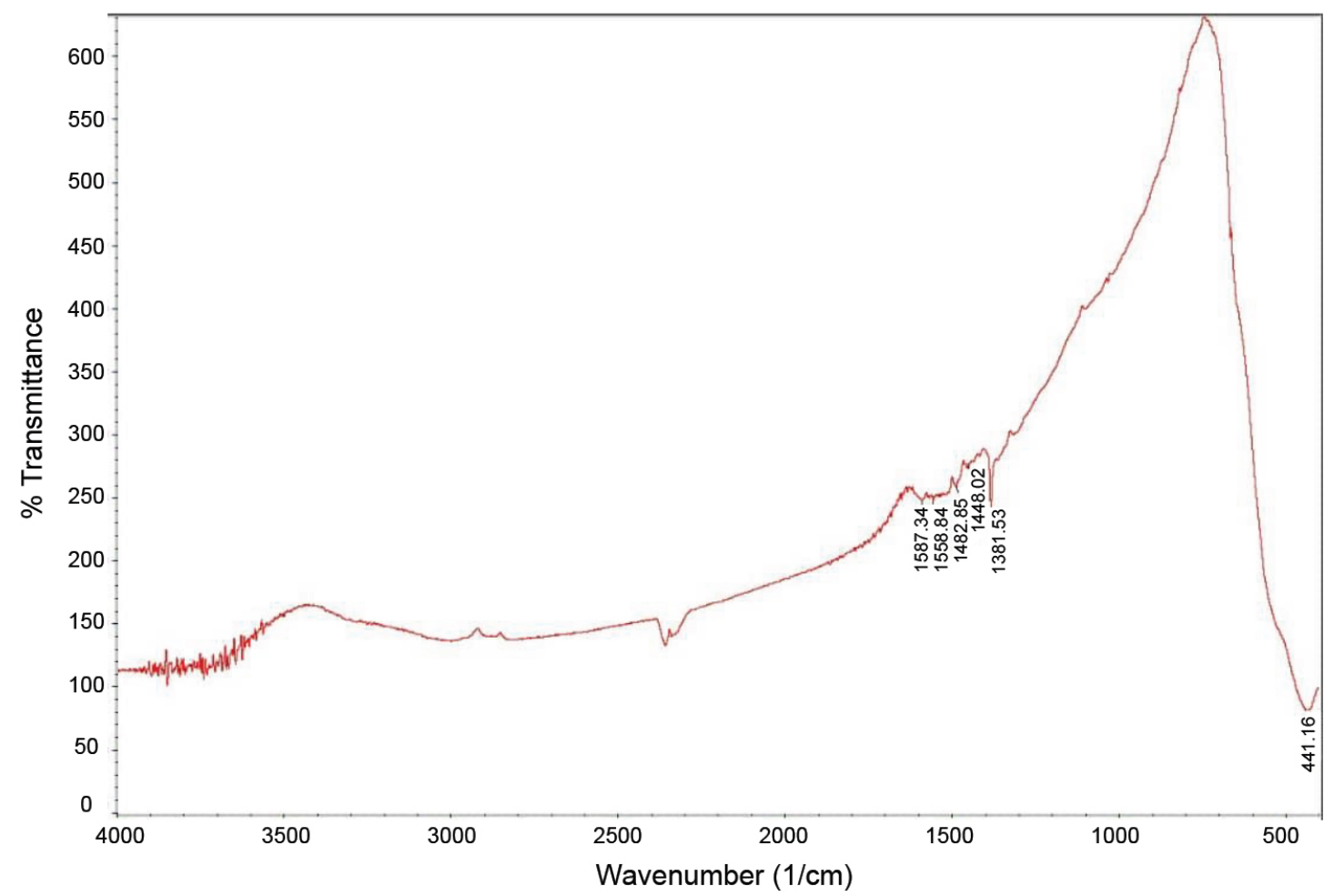

Fig. S8. FTIR spectrum of $\mathrm{Fe}-\mathrm{Ni}-\mathrm{Co}-\mathrm{ZnO}$ catalyst. 


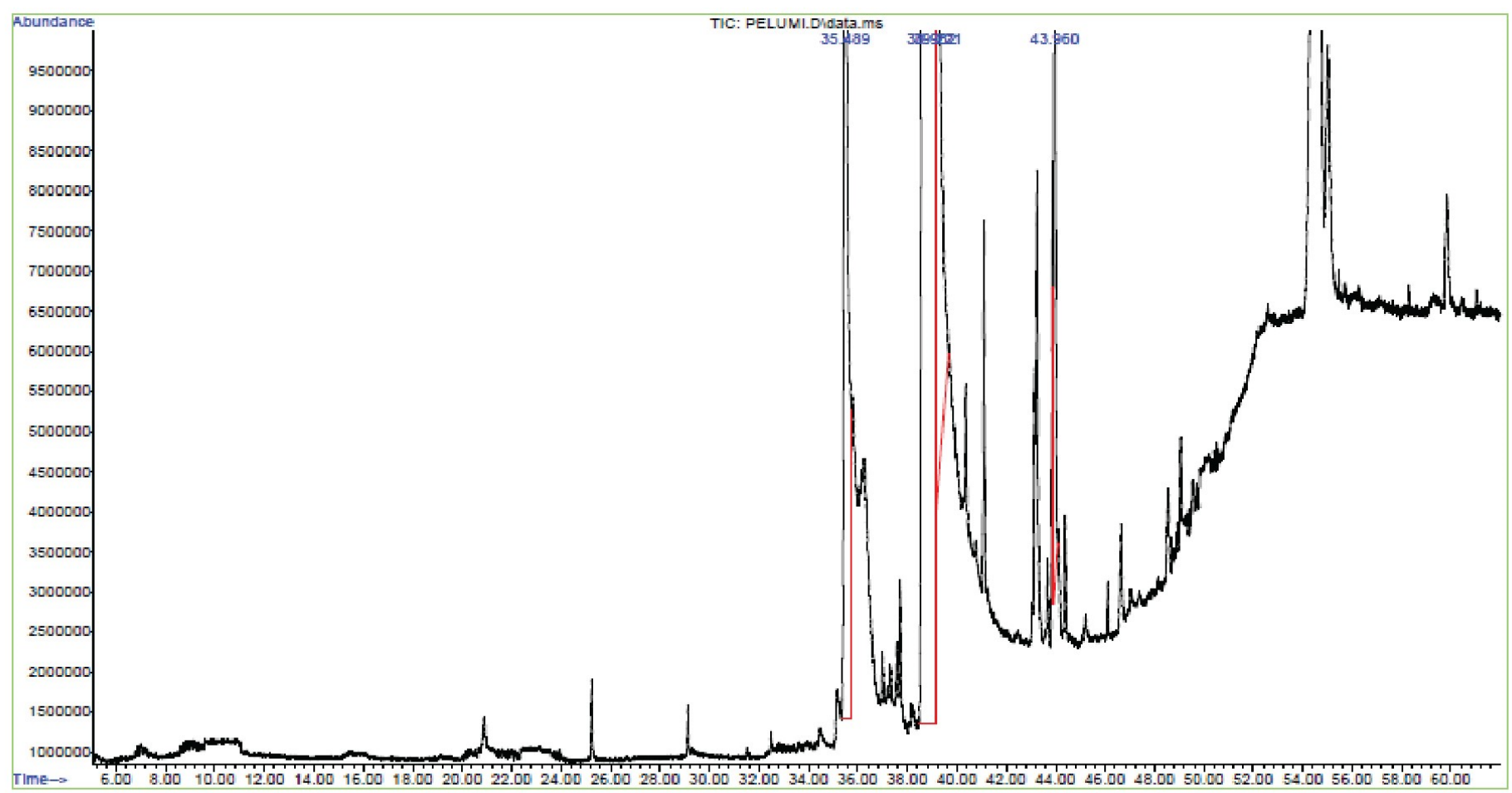

Fig. S9. FAME profile of the biodiesel produced by $\mathrm{Fe}-\mathrm{Co}-\mathrm{Ni} / \mathrm{MgO}$.

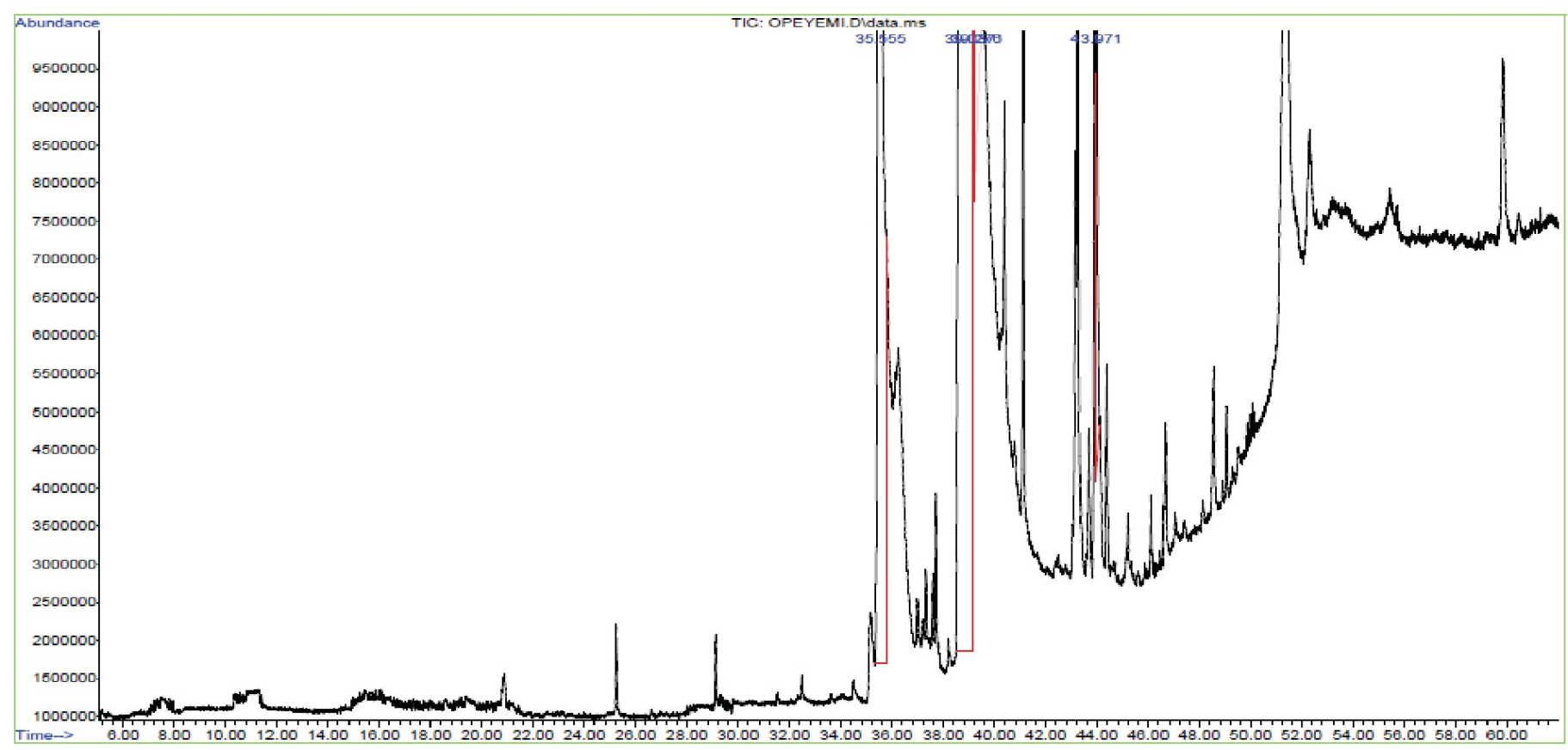

Fig. S10. FAME profile of the biodiesel produced by $\mathrm{Fe}-\mathrm{Co}-\mathrm{Ni}-\mathrm{MgO}$. 


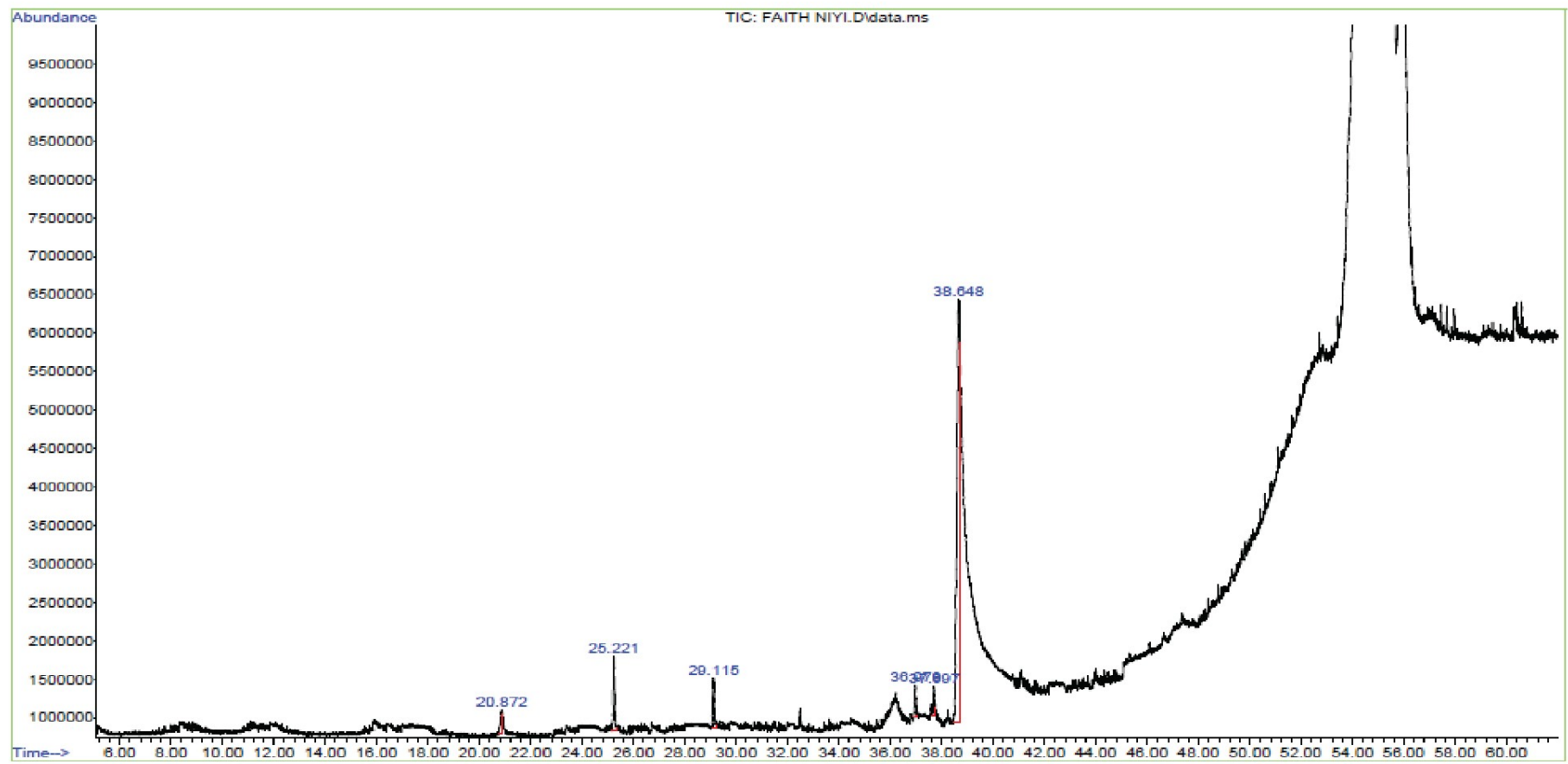

Fig. S11. FAME profile of the biodiesel produced by $\mathrm{Fe}-\mathrm{Co}-\mathrm{Ni} / \mathrm{ZnO}$.

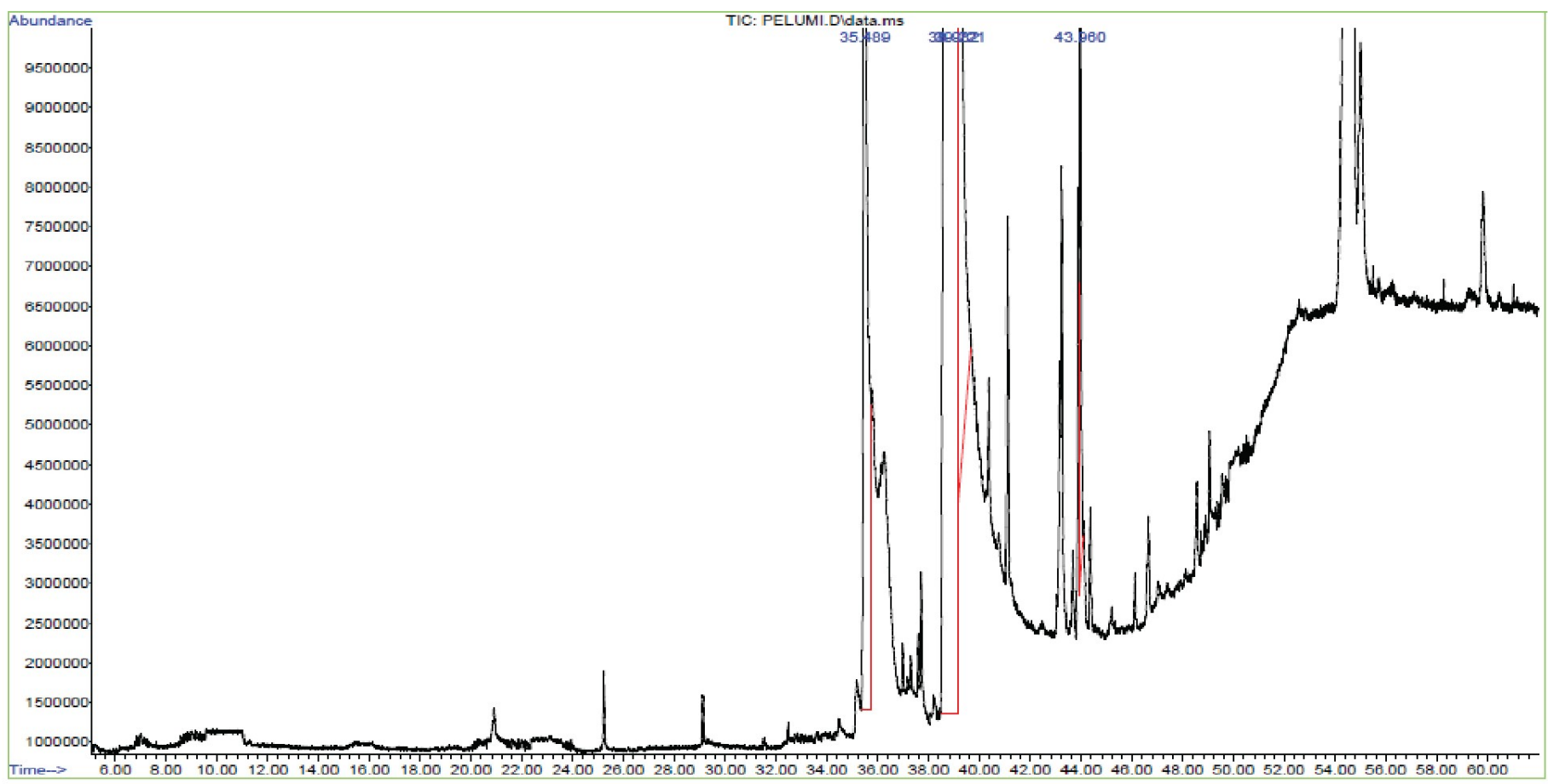

Fig. S12. FAME profile of the biodiesel produced by $\mathrm{Fe}-\mathrm{Co}-\mathrm{Ni}-\mathrm{ZnO}$.

Please cite this article as: Aderibigbe F.A., Mustapha S.I., Adewoye T.L., Mohammed I.A., Gbadegesin A.B., Niyi F.E., Olowu O.I., Soretire A.G., Saka H.B. Qualitative role of heterogeneous catalysts in biodiesel production from Jatropha curcas oil. Biofuel Research Journal 26 (2020) 1159-1169. DOI: 10.18331/BRJ2020.7.2.4 
Design-Expert@ Software

Factor Coding: Actua

- Design points above predicted value

Yield ((\%))

- Design points above predicted value

41.9

$\mathrm{X} 1=\mathrm{A}: \mathrm{MeOH}: \mathrm{O}$

$\mathrm{X} 2=\mathrm{B}:$ Temp

Actual Factors

C: Cat Conc $=10$

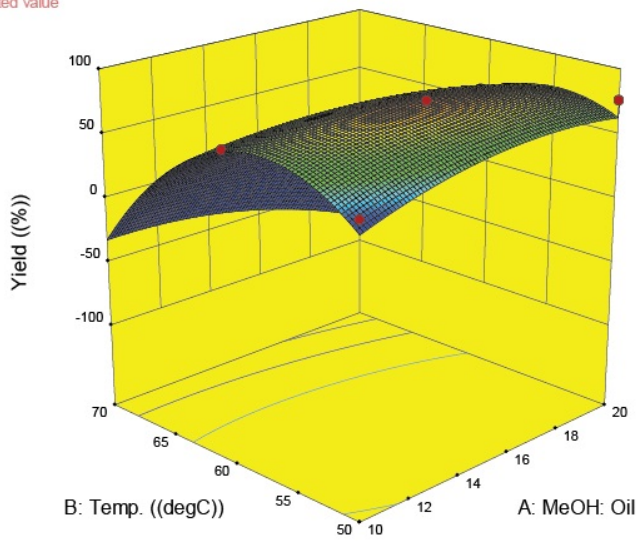

$\mathrm{X}_{1}=\mathrm{A} \cdot \mathrm{MeOH}: \mathrm{OI}$
$\mathrm{X}_{2}=\mathrm{C}$ : Time

Actual Factors
B. Temp 060
$D$. Can

D. Cat. Conc. $=10$

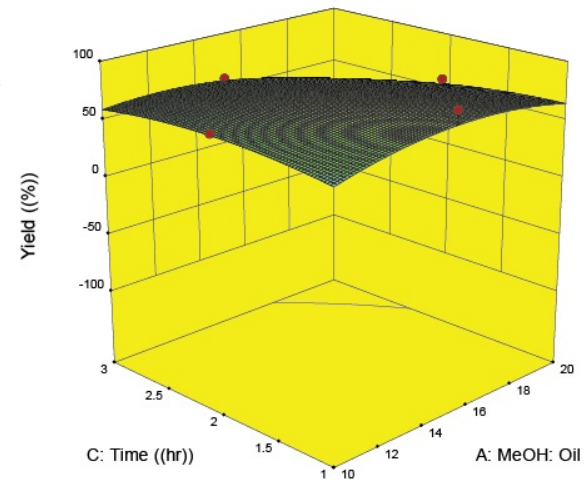

Design-Expertø Software

Factor Coding. Actual

- Design points above predicted value

Factor-Expert? Softw

Yield ((\%))

- Design points below predicted value

41.9

X1 = B: Temp.

X1 = B: Temp.
X2 = D: Cat. Conc.

Actual Factors

A: $\mathrm{MeOH}:$ Oil $=$
C. Time $=2$
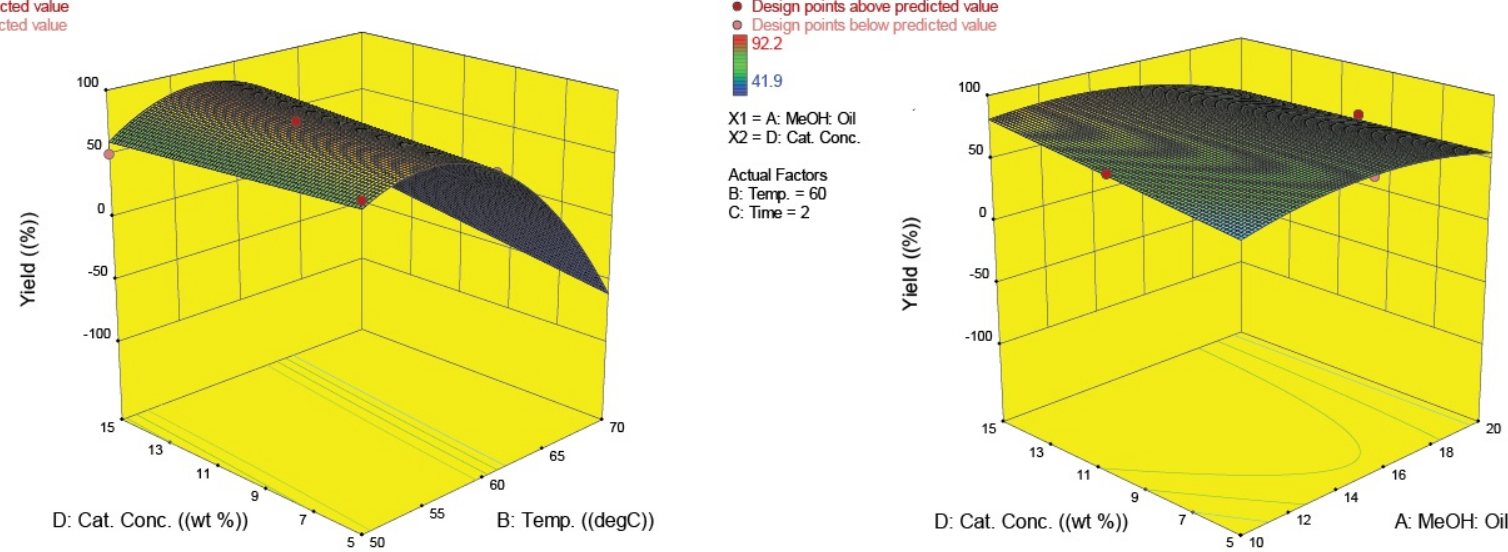

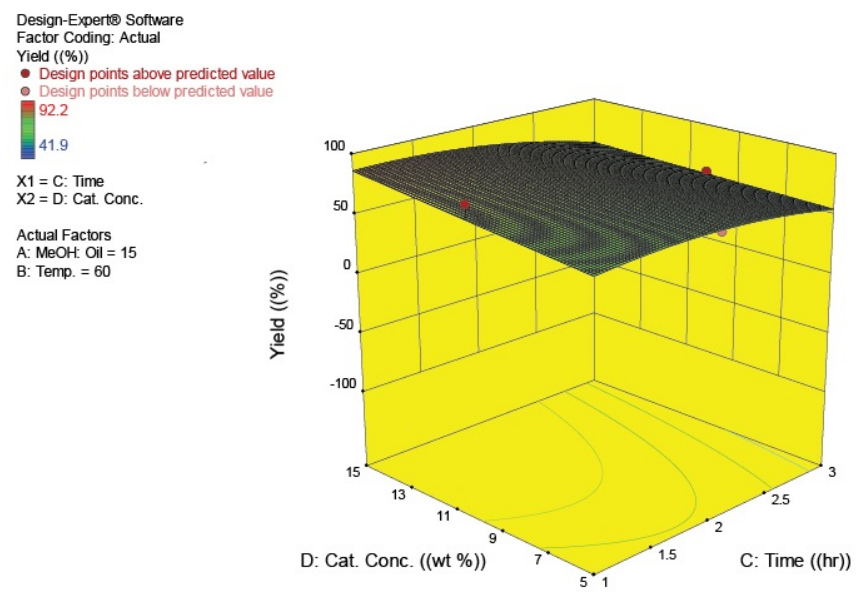

Fig. S13. Interactive effects of the transesterification parameters using $\mathrm{Fe}-\mathrm{Co}-\mathrm{Ni} / \mathrm{MgO}$

Please cite this article as: Aderibigbe F.A., Mustapha S.I., Adewoye T.L., Mohammed I.A., Gbadegesin A.B., Niyi F.E., Olowu O.I., Soretire A.G., Saka H.B. Qualitative role of heterogeneous catalysts in biodiesel production from Jatropha curcas oil. Biofuel Research Journal 26 (2020) 1159-1169. DOI: 10.18331/BRJ2020.7.2.4 
Design-Experte Software

Factor Coding: Adua

Meld ((\%))

- Design paints below predicleded value

26.9

$\mathrm{X} 1=\mathrm{A}: \mathrm{MeOH}:$ Oil

Actual F actors
C. Time $=2$

C: Time $=2$
D: Cat Conc $=10$

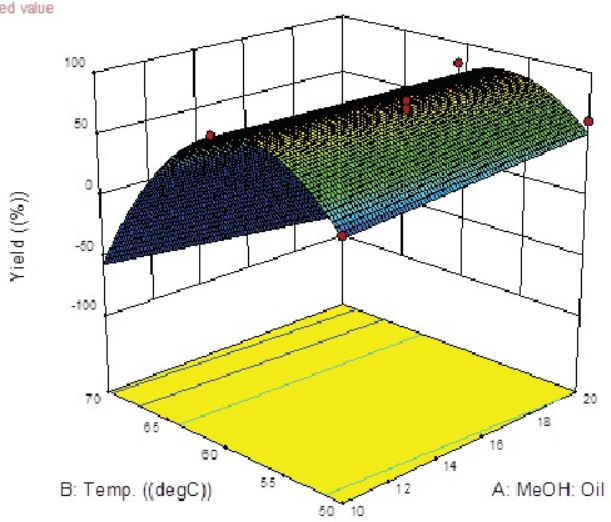

Design-Experto Software

Factor Coding: Actu

- Design pas

Design points belowpredicted value

26.9

$\mathrm{X} 1=\mathrm{A} \cdot \mathrm{MeOH}: \mathrm{Oil}$

$\mathrm{X} 2=\mathrm{D}$ : C at Canc.

Actual Factors

B: Temp. $=60$
C: Time $=2$

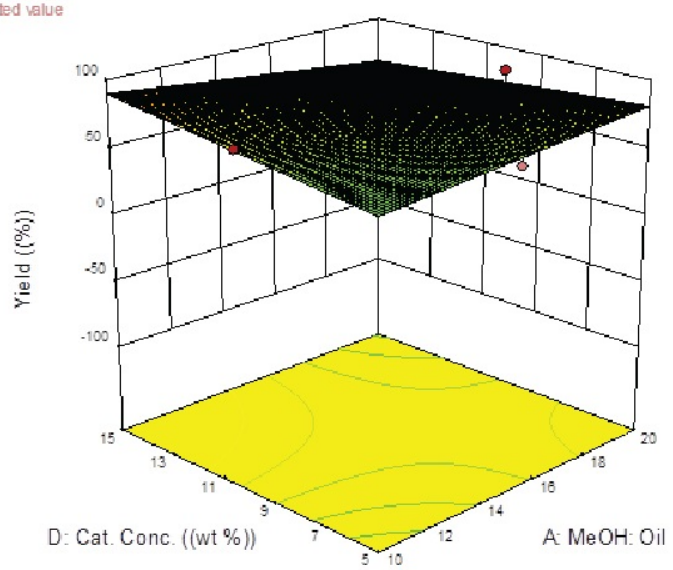

Desibn-Expents Sothuse

Held (ISi) ants above prescted value

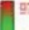

$\mathrm{XI}_{1}=\mathrm{A}, \mathrm{HeOH}_{\mathrm{O}} \mathrm{O}$

Adual Frodors
E. Tarn $=60$

D. Cat Conc $=10$

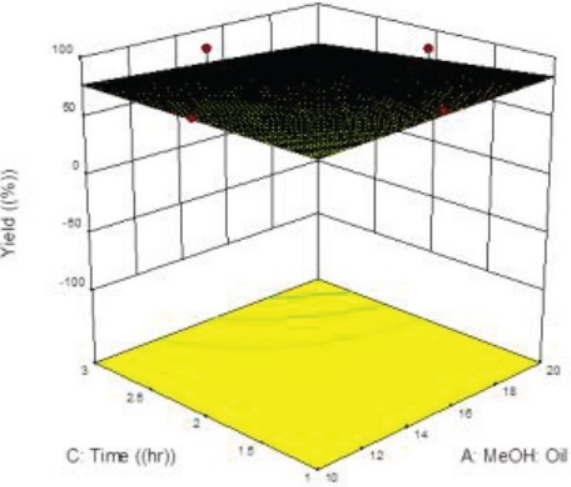

Design-Experta Sotware Factor Coding: Actua

- Design points abave predicted value

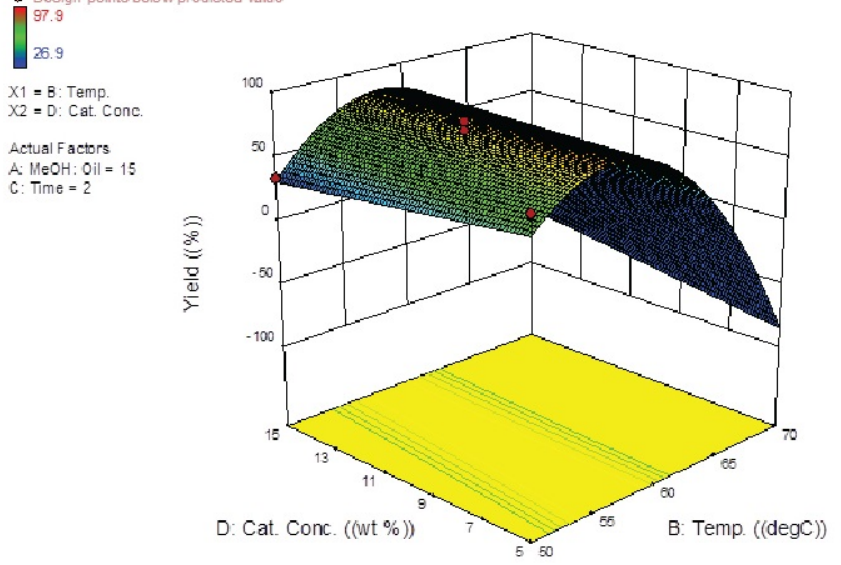

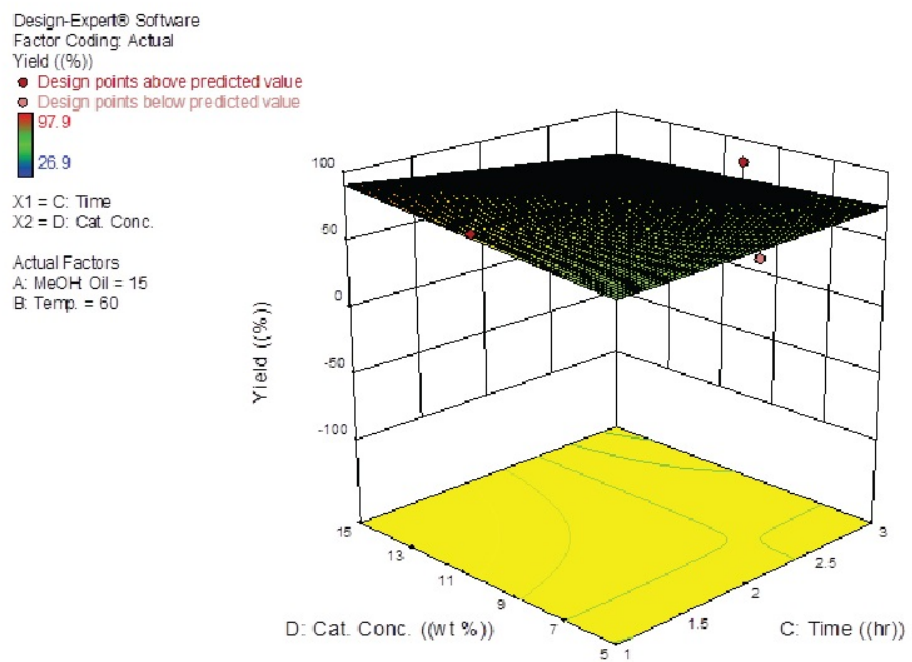

Fig. S14. Interactive effects of the transesterification parameters using $\mathrm{Fe}$ - $\mathrm{Co}-\mathrm{Ni}-\mathrm{MgO}$. 
Design-Experte Software
Factor Coding: Actual

Factor Codin:
Yield ((\%))

- Design points above predicted value

Design points below predicted value

20.8

$\mathrm{X} 1=\mathrm{A}:$ MeOH: Oil

$\mathrm{X}_{2}=\mathrm{B}$ : Temp.

Actual Factors

C: Time $=2$

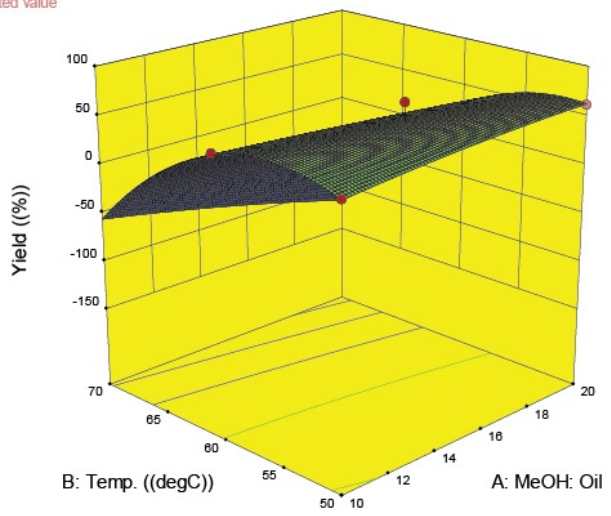

Design-Expert@ Software

Factor Coding: Actual

Yield ((\%))

- Design points above predicted value

- Design points below predicted value

86.6
20.8

$\mathrm{X} 1=\mathrm{A}: \mathrm{MeOH}:$ Oil $\mathrm{X} 2=\mathrm{D}$ : Cat conc.

Actual Factors

B: Temp. $=60$

C. $T$ me $=2$

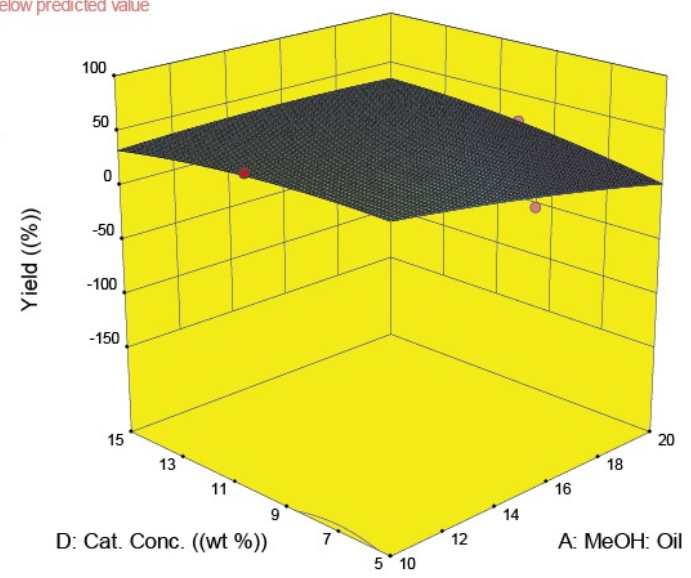

Design-Expertø Software

Factor Coding: Actual

Factor Co

- Design points above predicted value

- Design points below predicted valte

20.6
20.8
$\mathrm{X} 1=\mathrm{A}:$ MeOH: Oil
$\mathrm{X} 2=\mathrm{C}:$ Time
Actual Factors
B: Temp. $=60$
D: Cat. Conc. $=10$

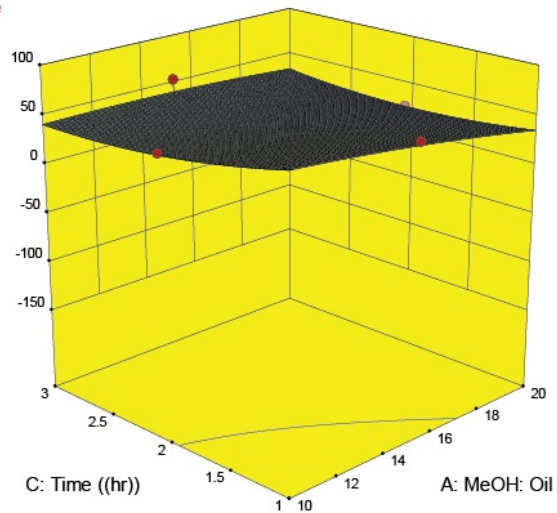

Design-Expert@ Softwar
Factor Coding: Actual

Factor Coding: Actual

Yield ((\%))

- Design points above predicted value

86.6

20.8

$\mathrm{X}_{1}=\mathrm{B}:$ Temp.

Actual Factors

A: MeOH: Oil $=15$
D: Cat. Conc. $=10$

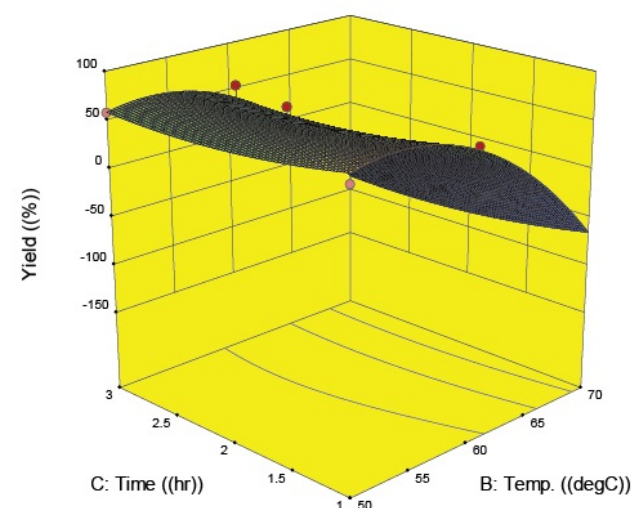

Design-Expert冈 Software

Factor Coding:

Yield ((\%)) Design points above predicted value

- Design points above predicted valus below predicted value

20.8

$\mathrm{X} 1=\mathrm{C}:$ Time

X2 $=$ D: Cat. Conc

Actual Factors
A: MeOH: Oil $=15$ A: MeOH: : $1=$

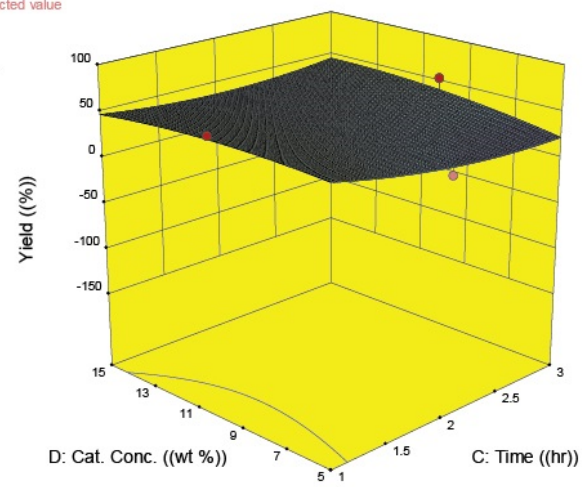

Fig. S15. Interactive effects of the transesterification parameters using $\mathrm{Fe}$ - $\mathrm{Co}-\mathrm{Ni} / \mathrm{ZnO}$

Please cite this article as: Aderibigbe F.A., Mustapha S.I., Adewoye T.L., Mohammed I.A., Gbadegesin A.B., Niyi F.E., Olowu O.I., Soretire A.G., Saka H.B. Qualitative role of heterogeneous catalysts in biodiesel production from Jatropha curcas oil. Biofuel Research Journal 26 (2020) 1159-1169. DOI: 
Design-Expert@ Software
Factor Coding: Actual

Yied ((\%))
: Design points above predicted value
- Design points below predicted value

91.4
22.4

$\mathrm{X}_{1}=\mathrm{A}: \mathrm{MeOH}$ Oil
$\mathrm{X}_{2}=\mathrm{B}:$ Temp.

Actual Factors

C: Time $=2$
D: Cat. Conc. $=10$

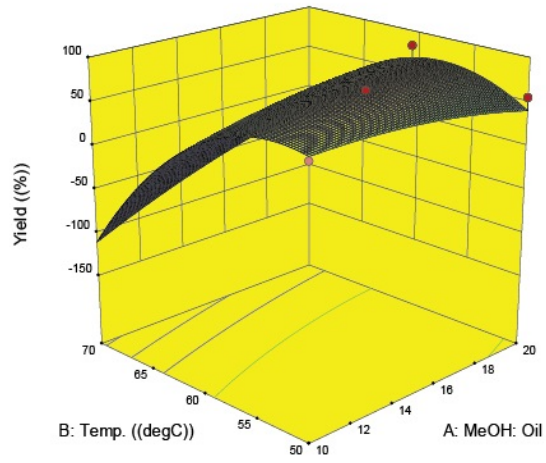

Design-Expernø Software

Yield ((\%))

- Design points below predicted value

22.4

$\mathrm{X} 1=\mathrm{A}:$ MeOH: Oil
$\mathrm{X}_{2}=\mathrm{D}:$ Cat

Actual Factors

Actual Factors
B: Temp. $=60$
C: Time $=2$

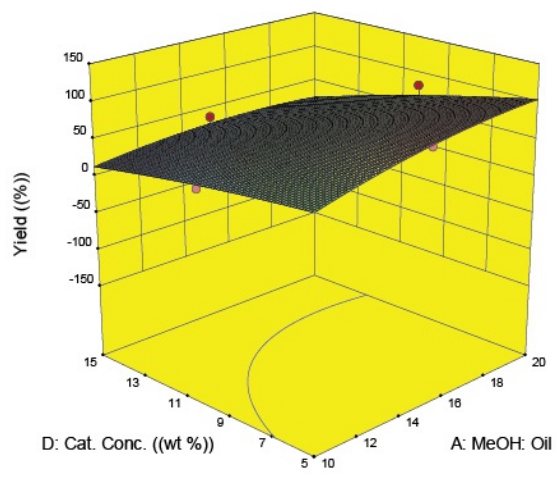

Design-Exper(《) Software

Yield ((\%))

- Design points above predicted value

- Design points below predicted value

- Desig

22.4

X1 = B: Temp.

$X 2=\mathrm{D}:$ Cat. Conc.

Actual Factors

C. Time $=2$

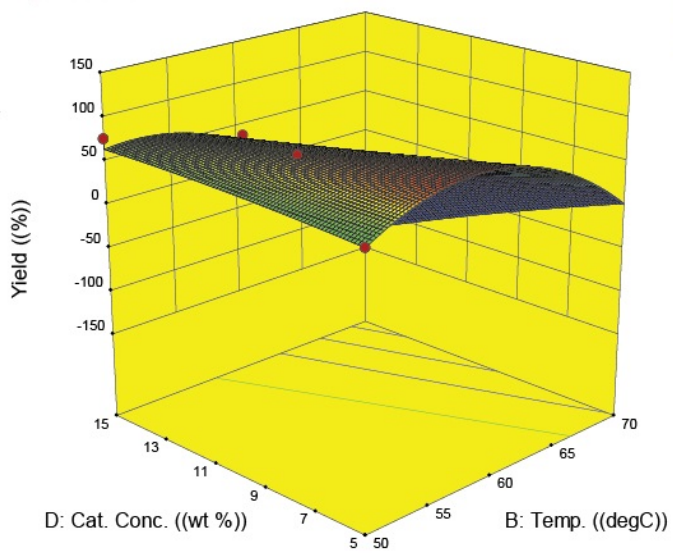

Design-Expertø Software

Factor Coding: Actur
Yield ((\%))

- Design points above predicted value

- Design points above predicted value
91.4

22.4

$\mathrm{X}_{1}=\mathrm{A}: \mathrm{MeOH}: \mathrm{O}$

Actual Factors

Conc. $=10$
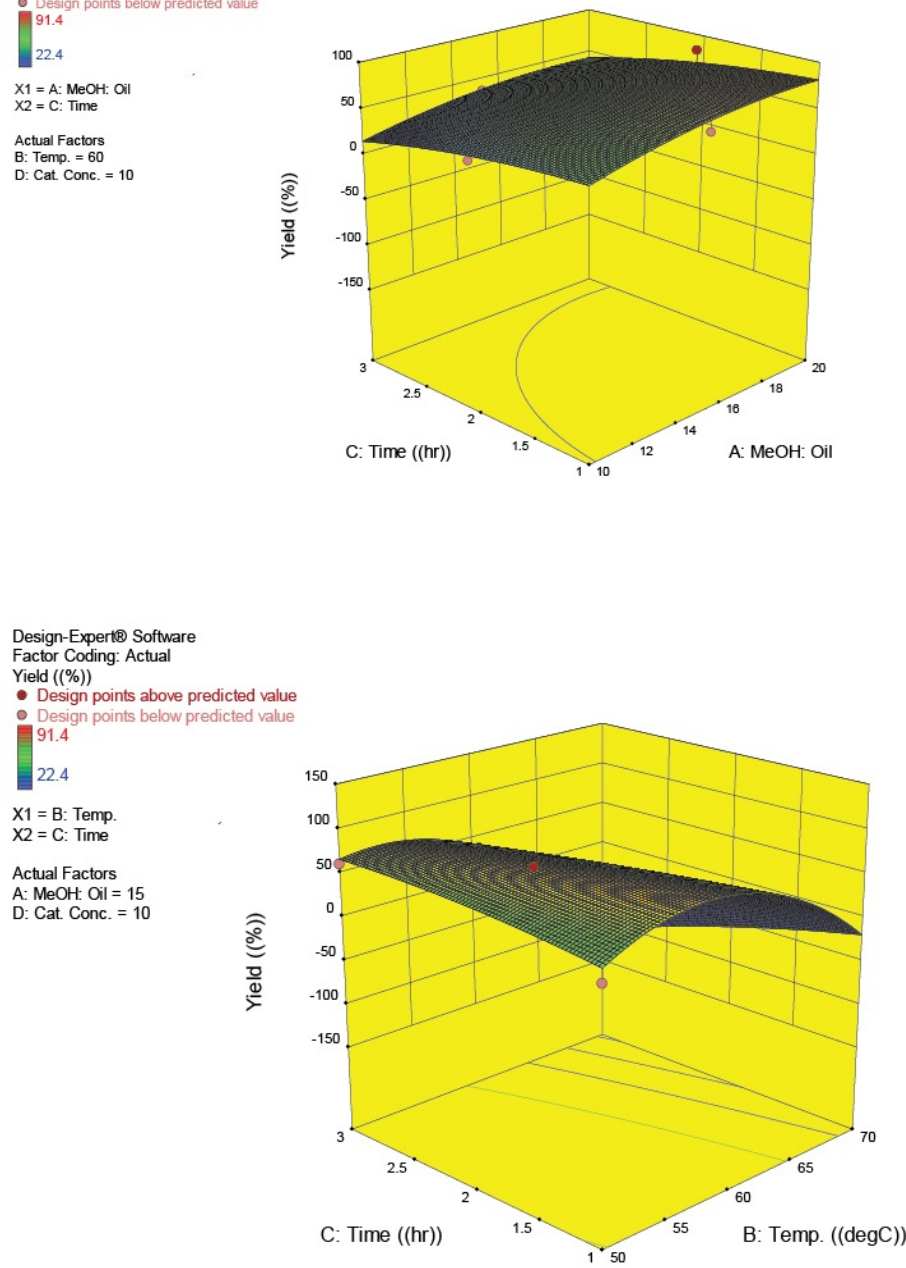

Design-Expert@ Software

Factor Coding: Actular

- Design points above predicted value

Design points below predicted value

22.4

X1 = C: Time

Actual Factors

A: $\mathrm{MeOH}:$ Oil $=15$

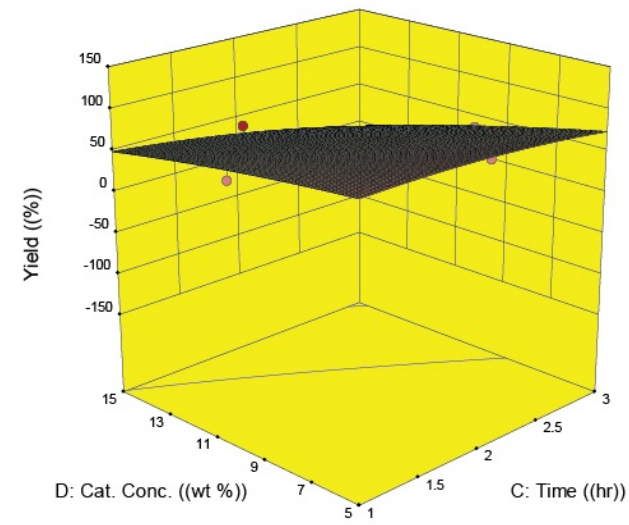

Fig. S16. Interactive effects of the transesterification parameters using $\mathrm{Fe}-\mathrm{Co}-\mathrm{Ni}-\mathrm{ZnO}$

Please cite this article as: Aderibigbe F.A., Mustapha S.I., Adewoye T.L., Mohammed I.A., Gbadegesin A.B., Niyi F.E., Olowu O.I., Soretire A.G., Saka H.B. Qualitative role of heterogeneous catalysts in biodiesel production from Jatropha curcas oil. Biofuel Research Journal 26 (2020) 1159-1169. DOI: 10.18331/BRJ2020.7.2.4 